\title{
Voltage-Gated Potassium Channels in Larval CNS Neurons of Drosophila
}

\author{
Charles K. Solc and Richard W. Aldrich \\ Department of Neurobiology, Stanford University School of Medicine, Stanford, California 94305
}

The availability of genetic, molecular, and biophysical techniques makes Drosophila an ideal system for the study of ion channel function. We have used the patch-clamp technique to characterize voltage-gated $\mathrm{K}^{+}$channels in cultured larval Drosophila CNS neurons. Whole-cell currents from different cells vary in current kinetics and magnitude. Most of the cells contain a transient A-type 4-AP-sensitive current. In addition, many cells also have a more slowly inactivating TEA-sensitive component and/or a sustained component. No clear correlation between cell morphology and whole-cell current kinetics was observed. Single-channel analysis in cell-free patches revealed that 3 types of channels, named $A_{2}, K_{D}$, and $K_{1}$ can account for the whole-cell currents. None of these channels requires elevated intracellular calcium concentration for activation. The $A_{2}$ channels have a conductance of 6-8 pS and underlie the whole-cell $A$ current. They turn on rapidly, inactivate in response to depolarizing voltage steps, and are completely inactivated by prepulses to $-50 \mathrm{mV}$. The $\mathrm{K}_{\mathrm{D}}$ (delayed) channels have a conductance of 10-16 pS and can account, in part, for the more slowly inactivating component of whole-cell current. They have longer open times and activate and inactivate more slowly than the $A_{2}$ channels. The $K_{1}$ channels have a slope conductance, measured between 0 and $+40 \mathrm{mV}$, of 20-40 ps. These channels do not inactivate during $\mathbf{5 0 0}$ msec voltage steps and thus can contribute to the sustained component of current. They exhibit complex gating behavior with increased probability of being open at higher voltages. Although the $K_{1}$ channels are sufficient to account for the noninactivating component of whole-cell current, we have observed several other channel types that have a similar voltage dependence and average kinetics.

Neuronal cell membranes have a variety of distinct potassium channels that can be activated by changes in membrane voltage (see reviews by Latorre et al., 1984, and Rudy, 1988). The relative number and spatial distribution of these channels in the cell determine the particular excitability properties of a given neuron, ranging from integration of synaptic inputs to the capability for low-frequency repetitive firing, adaptation in firing

\footnotetext{
Received Aug. 12, 1987; revised Nov. 5, 1987; accepted Nov. 6, 1987

We wish to thank Drs. D. Baylor, S. Germeraad, T. Hoshi, and D. O'Dowd for critical comments on the manuscript. This work was supported by NS 23294 , a Searle Scholar's Program/Chicago Community Trust fellowship to R.W.A. and an Alfred P. Sloan Research Fellowship and an NSF graduate fellowship to C.K.S.

Correspondence should be addressed to C. K. Solc at the above address.

Copyright ( 1988 Society for Neuroscience $0270-6474 / 88 / 072556-15 \$ 02.00 / 0$
}

frequency or pacemaking activity (see reviews by Adams et al., 1980; Thompson and Aldrich, 1980; Adams and Galvan, 1986). Information about the gating of voltage-dependent $\mathrm{K}^{+}$channels can lead to a better understanding of the mechanisms underlying these properties.

The gating of neuronal potassium channels has been extensively studied using the voltage-clamp technique, and several components of macroscopic $\mathrm{K}^{+}$current have been identified. They include the transient A-type current, the delayed $\mathrm{K}$ ' current, the inward rectifier current, and the calcium-dependent $\mathrm{K}^{+}$ current (see reviews by Thompson and Aldrich, 1980, and Adams and Galvan, 1986). The recent application of single-channel recording has revealed that several channel types can contribute to each of these components, such that a single cell may have over a half-dozen different voltage-dependent $\mathrm{K}^{+}$channels. This diversity raises interesting questions regarding the structural relationships between the different $\mathrm{K}^{+}$channels, which can best be answered through a combination of biophysical and molecular techniques.

We therefore chose to examine $\mathrm{K}^{+}$channels in Drosophila neurons. The combination of genetic, molecular, and biophysical techniques available in Drosophila provides a powerful approach for the analysis and isolation of channel molecules, manipulation of their structure, and assessment of their role in the development and behavior of a functioning organism. Several mutations, isolated on the basis of behavioral abnormalities, have been proposed to affect $\mathrm{K}^{+}$channels due to their effects on muscle and neuronal excitability (Jan et al., 1977; Tanouye et al., 1981; Ganetzky and Wu, 1983; also see reviews by Ganetzky and Wu, 1986; Salkoff and Tanouye, 1986; Tanouye et al., 1986; Papazian et al., 1988). Voltage-clamp analysis of macroscopic $\mathrm{K}^{+}$currents has been useful in determining the effects of these mutations in muscle (Salkoff and Wyman, 1981b; Wu et al., 1983a; Wu and Haugland, 1985; Elkins et al., 1986; Timpe and Jan, 1987), but the small size and inaccessibility of Drosophila neurons have precluded a voltage-clamp analysis of $\mathrm{K}^{+}$currents in these cells in vivo. Primary cultures of neurons dissociated from larval brain (Wu et al., 1983b), however, are well suited for patch-clamp analysis (Sun and $\mathrm{Wu}, 1984$; Solc and Aldrich, 1985; Solc et al., 1987; Yamamoto and Suzuki, 1987). In the present study, we have used the patch-clamp technique to characterize voltage-dependent $\mathrm{K}^{+}$channels in this preparation at the whole-cell and at the single-channel levels. This characterization of voltage-dependent $\mathrm{K}^{+}$channels in wild-type neurons is necessary for determining the effects of the various neuronal excitability mutants at the single-channel level. A preliminary report of part of this work has appeared (Solc and Aldrich, 1986). 


\section{Materials and Methods}

Fly stocks. All of the experiments illustrated in the figures were done using cells from Canton S wild-type Drosophila. The stocks were maintained on cornmeal-yeast-dextrose medium in an incubator at $22^{\circ} \mathrm{C}$.

Cell culture. Neuronal cultures were prepared by a method similar to that used by Wu ct al. (1983b). Bctween 10-15 late third instar larvae were collected and washed in 70\% ethanol for 1-2 min. Brain and ventral ganglion complexes were dissected in PBS, mechanically teased to rupture the neurolemma, and incubated for $45-75 \mathrm{~min}$ in a calcium $/ \mathrm{mag}$ nesium-free PBS solution containing $0.5 \mathrm{mg} / \mathrm{ml}$ collagenase (type $\mathrm{I}$, Sigma). The preparation was centrifuged for $1-2 \mathrm{~min}$ at $3000-4000$ $\mathrm{rpm}$, and the supernatant was discarded. The pellet was resuspended in modified Schneider's medium (Gibco) supplemented with $1.5 \%$ penicillin/streptomycin and 10 or $20 \%$ fetal calf serum (Gibco, Hazleton); the cells were triturated until clumps of tissue were no longer visible and plated on $12 \mathrm{~mm}$ round autoclaved coverslips at a density of $1 / 2-1$ brain/ganglion complex per coverslip. An extra coverslip was sometimes placed on top of the cells, as this improved the viability of cells in the older cultures. Initially, some coverslips were coated with polylysine or polyornithine, but we found no obvious difference between cultures on coated and uncoated glass and subsequently used only the uncoated variety. The cultures were maintained in $35 \mathrm{~mm}$ dishes with $1.5-2 \mathrm{ml}$ of medium at $19-22^{\circ} \mathrm{C}$ for $1-12 \mathrm{~d}$ before voltage-clamp experiments were conducted.

The distribution of cell types in cultures immediately after plating was similar to that described by Wu et al. (1983b). These investigators classified the cells into 3 types according to size: large $(>8 \mu \mathrm{m})$ round undifferentiated type I neuroblast-like cells; small $(2-5 \mu \mathrm{m})$ type II neurons; and intermediate sized (5-10 $\mu \mathrm{m})$ type III neurons. The type III neurons usually had a short, thick process extending from one or both ends of an oval or spindle-shaped cell body, while type II neurons had a single primary process extending from the side of a round cell body. Cells with typical glial morphology (Strausfeld, 1976; Sang, 1981) were rarely seen. $\Lambda$ fter a few days in culture, many of the typc III ncurons differentiated into round, $8-12 \mu \mathrm{m}$ multipolar cells with a dense network of processes radiating out from underneath the cell body. Cells with this morphology stained with the anti-HRP antibody, which stains neurons in Drosophila (Jan and Jan, 1982), and were used for most of the experiments in this study.

Electrophysiology. Cells ranging from 5 to $12 \mu \mathrm{m}$ in diameter were voltage-clamped using the whole-cell and cell-free patch recording methods (Hamill et al., 1981). The electrodes had resistances of 3-15 M 2 when filled with the standard solutions described below. The pipette junction potential was nulled immediately before obtaining a tight-seal on the cell. The voltages given in this study were not corrected for the junction potential, which was estimated to be less than $5 \mathrm{mV}$ from the reversal potentials measured for $\mathrm{K}^{+}$channels in symmetrical potassium solutions. Whole-cell input resistances were typically 10-30 G $\Omega$, though values approaching $100 \mathrm{G} \Omega$ were obtained in some of the smaller cells. The data were recorded with a List EPC-7 or Axon Instruments Axopatch patch-clamp amplifier and analyzed on a Digital Equipment Corporation PDP 11/73 microcomputer.

Initially, the cells chosen for experiments were selected at random. The kinetics of the outward currents in different cells varied considerably, but we did not observe an obvious correlation between kinetics and cell morphology. In subsequent experiments, we used differentiated multipolar type III cells, which typically had larger currents than other cells in the culture. Furthermore, in a subset of these cells, the cell body could be lifted off the coverslip, and separated from the processes, which remained attached to the glass. This manipulation enabled us to record currents from the soma with minimal contribution of currents from processes under poor voltage control and eliminated stability problems associated with electrode drift. We saw no consistent difference between currents recorded in this manner and currents from cells with intact processes.

The ionic composition of the standard bath solution was (in $\mathrm{mm}$ ): $140 \mathrm{NaCl}, 2 \mathrm{KCl}, 4 \mathrm{MgCl}_{2}, 2 \mathrm{CaCl}_{2}, 5$ HEPES $(\mathrm{NaOH}), \mathrm{pH} \mathrm{7.1-7.2}$. The internal solution contained (in $\mathrm{mM}$ ): $70 \mathrm{KF}, 70 \mathrm{KCl}, 2 \mathrm{MgCl}_{2}, 11$ EGTA, $1 \mathrm{CaCl}_{2}, 10 \mathrm{HEPES}(\mathrm{KOH}), \mathrm{pH} 7.1-7.2$. The calculated internal free calcium concentration was approximately $10 \mathrm{nM}$. In one experiment (indicated in the legend for Fig. 1), we substituted $70 \mathrm{~mm} \mathrm{KCl}$ for 70 mM KF in the internal solution. The high $\mathrm{K}^{+}$bath solution contained (in mM): $140 \mathrm{KCl}, 4 \mathrm{MgCl}_{2}, 2 \mathrm{CaCl}_{2}, 5$ HEPES (KOH), $\mathrm{pH}$ 7.1-7.2. All experiments were conducted at room temperature $\left(19-23^{\circ} \mathrm{C}\right)$.

Whole-cell current recordings were low-pass filtered with an 8-pole
Bessel filter and digitized at frequencies indicated in the figure legends. Linear leakage and uncompensated capacity currents were subtracted using a scaled average of currents elicited by 16-32 $20 \mathrm{mV}$ depolarizations from the holding potential. Series resistance compensation was not routinely used. Over $95 \%$ of the whole-cell currents recorded were less than $1 \mathrm{nA}$ at $+40 \mathrm{mV}$. Assuming a series resistance of $15 \mathrm{M} \Omega$ (twice the average pipette resistance), a 1 nA current would give a series resistance error of $15 \mathrm{mV}$. In one instance, we recorded currents from a cell (shown in Fig. $1 B$ ) with currents larger than $1 \mathrm{nA}$ both with $(90 \%$ compensation) and without series resistance compensation, and observed no difference in the kinetics of the current.

Single-channel current records were filtered and digitized at frequencies indicated in the figure legends. For voltage-step experiments, leakage and uncompensated capacity currents were digitally subtracted during analysis using leak templates constructed by fitting smooth functions to sweeps with no openings. The current records were idealized using a 50\% amplitude criterion (Colquhoun and Sigworth, 1983). Ensemble averages were generated from the idealized data. Ensemble averages expressed in probability units were calculated by dividing the current averages (in units of $\mathrm{pA}$ ) by the number of channels in the patch and the single-channel current amplitude. The number of active channels was determined by counting the maximum number of channels open at one time. Single-channel voltage-ramp records were leak-subtracted using smooth templates fitted to records with no openings.

\section{Results}

The results and conclusions presented in this paper are based on observations made in over 180 whole-cell and 70 cell-free patch experiments on cells from over 80 separate culture preparations.

\section{Heterogeneity of whole-cell currents}

The majority of cells exhibited only net outward currents in response to depolarizing step pulses. In a few cells, a small $\mathrm{Cd}^{2+}$ sensitive inward current was apparent at low voltages $(-40$ to $-30 \mathrm{mV}$ ). Its sensitivity to $1 \mathrm{mM} \mathrm{Cd}^{2+}$ and tendency to disappear with time suggested that this was a voltage-sensitive $\mathrm{Ca}^{2+}$ current, but it was not studied in isolation. We saw no evidence of voltage-dependent $\mathrm{Na}^{+}$currents in 1-12 d cells, but occasionally observed $\mathrm{Na}^{+}$spikes in older cells. The lack of persistent inward currents enabled us to characterize the outward currents in the absence of $\mathrm{Na}^{+}$and $\mathrm{Ca}^{2+}$ channel blockers.

Outward currents recorded from differentiated Inulipolar neurons at similar times in culture had different kinetic properties. Figure 1 shows the range of whole-cell current patterns in response to depolarizing voltage steps observed in 4 neurons of similar culture age and morphology. In each case, the command voltage step was preceded by a prepulse sufficiently negative $(-90$ or $-100 \mathrm{mV})$ to remove inactivation from inactivating components of the current. Tail current experiments, to be described later, demonstrated that these currents were carried primarily by potassium.

Some cells (Fig. $1 A$ ) exhibited primarily a fast transient $\mathrm{K}^{+}$ current that turned on and inactivated rapidly in response to depolarizing voltage steps. The majority of the neurons, however, had $\mathrm{K}^{+}$currents with a slower inactivation timecourse (Fig. $\mathrm{l} B$ ). The activation time course in these cells was variable, ranging from relatively rapid activation (similar to that seen in Fig. $1 A$ ) to the slower time course apparent in Figure $1 B$. Many of the cells studied also expressed a noninactivating component of outward current. This component typically amounted to less than $20 \%$ of the peak current, but in some cells (Fig. $1 D$ ) it was relatively large. A small minority of the cells (5 out of over 180) contained primarily the noninactivating component (Fig. 1C). We did not observe an obvious correlation between culture age 
A

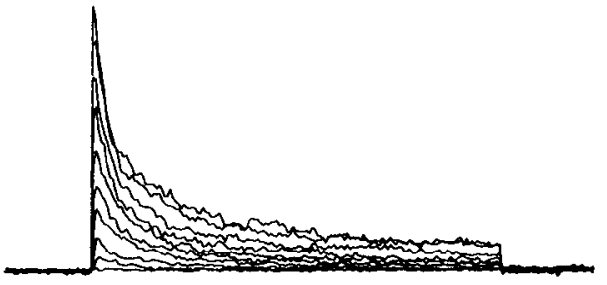

$100 \mathrm{pA}$

$75 \mathrm{msec}$

C

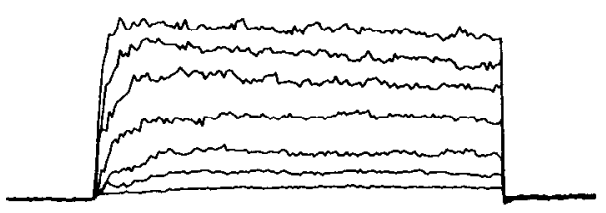

$100 \mathrm{pA}$

$75 \mathrm{msec}$
B

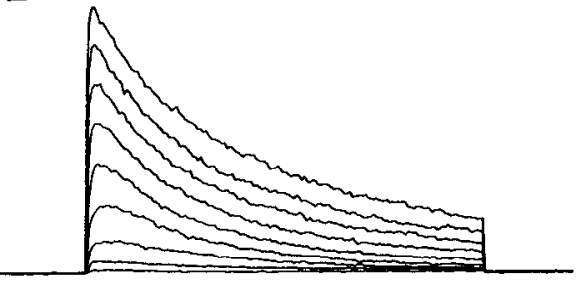

$400 \mathrm{pA}$

$100 \mathrm{msec}$

D

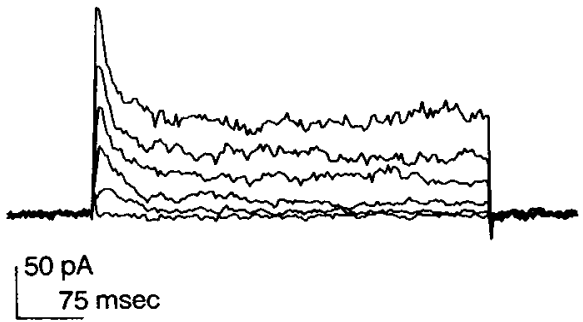

and the types of current patterns expressed, but because most of our experiments were on cells that had been in culture for at least $3 \mathrm{~d}$, we would not be aware of timing differences that occurred during the first $72 \mathrm{hr}$.

\section{Pharmacological isolation of current components}

In many cells, 2 inactivating components of current could be isolated at the whole-cell level based on their sensitivities to externally applied 4-amino-pyridine (4-AP) and tetraethyl ammonium ion ( $\mathrm{TEA}^{+}$). Figure $2 A$ shows the effect of $5 \mathrm{~mm} 4$-AP on whole-cell $\mathrm{K}^{+}$currents. The drug rapidly blocked a large fraction of the fast transient component (Fig. $2 A$, bottom). This component had kinetics very similar to the whole-cell currents in Figure $1 \mathrm{~A}$. The peak current was reduced in all of the cells treated with $5 \mathrm{mM} 4-\mathrm{AP}$, but the amount of block was variable from cell to cell. The onset of block was rapid, such that the current was typically reduced to $90 \%$ of the fully blocked value within $10 \mathrm{sec}$ of drug application. The block was always at least partially reversible, but the rate of recovery was slower than the onset of block.

Figure $2 B$ shows the effect of $\mathrm{TEA}^{+}$on whole-cell currents recorded from a different cell. $\mathrm{TEA}^{+}$reversibly blocked a slower component of the whole-cell current with no apparent effect on the fast transient component (Fig. $2 B$, top). Note that the TEAinsensitive component (Fig. $2 B$, top) had kinetics very similar to the 4-AP-sensitive component (Fig. $2 A$ bottom), while the 4-AP-insensitive component decayed with a time course similar to that of TEA-sensitive current (Fig. $2 B$, bottom). As was the case with 4-AP, the extent of block of the slowly inactivating component by $\mathrm{TEA}^{+}$was variable from cell to cell.

The variability in the kinetics of the whole-cell current and differential effects of 4-AP and $\mathrm{TEA}^{+}$suggested that several different channel types underlie the whole-cell $\mathrm{K}^{+}$current. We used single-channel recording methods to identify some of these channels and to characterize their gating behavior.

\section{Variety of single channels}

At least $3 \mathrm{~K}^{+}$channel types, distinguished by their conductance and gating behavior, could be activated by depolarizing pulses in cell-free patches. The extrapolated reversal potential for all 3 was between -60 and $-90 \mathrm{mV}$ in standard solutions and shifted to approximately $0 \mathrm{mV}$ in the presence of symmetrical $\mathrm{K}^{+}$. Figure 3 shows current traces from 2 outside-out patches that contained different types of channels. The records in Figure $3 A$ are from a patch that contained a few $7 \mathrm{pS}$ channels and a larger, $14 \mathrm{pS}$ channel. Although both channels inactivated during the command pulse, they could be readily distinguished. The smaller channels $\left(\mathrm{A}_{2}\right)$ had much shorter open durations and re-opened throughout the pulse. The larger channel $\left(\mathrm{K}_{\mathrm{D}}\right.$; delayed) had longer open durations and a lower re-opening frequency. The patch in Figure $3 B$ also contained $\mathrm{A}_{2}$ channels, along with a $37 \mathrm{pS}$ channel $\left(\mathrm{K}_{\mathrm{l}}\right)$. In contrast to the $\mathrm{A}_{2}$ and the $\mathrm{K}_{\mathrm{D}}$ channels, the $K_{1}$ channel was open with similar probability throughout the pulse (based on more traces at the same voltage). The most frequently observed $\mathrm{K}^{+}$channels were the $\mathrm{A}_{2}$ and $\mathrm{K}_{1}$ channels, present in approximately half of the patches containing channels (or about one-fourth of the total number of patches). The $\mathrm{K}_{\mathrm{D}}$ channels were seen less frequently, present in roughly $15 \%$ of patches with channels.

We have observed several other channel types in addition to the 3 mentioned above. Two of these were also selective for potassium (based on their reversal potentials) and did not inactivate during $500 \mathrm{msec}$ pulses. The first was a $60-80 \mathrm{pS}$ channel, which resembled the $K_{1}$ channel but opened at relatively low voltages. The second was a $40-50 \mathrm{pS}$ channel, which had extremely short open times, such that at our recording frequencies many openings did not reach the full single-channel current value. Another frequently observed channel was selective for $\mathrm{Cl}^{-}$and had a unitary conductance of 20-30 pS. The primary gating process was very slow (tens of seconds to minutes) and 


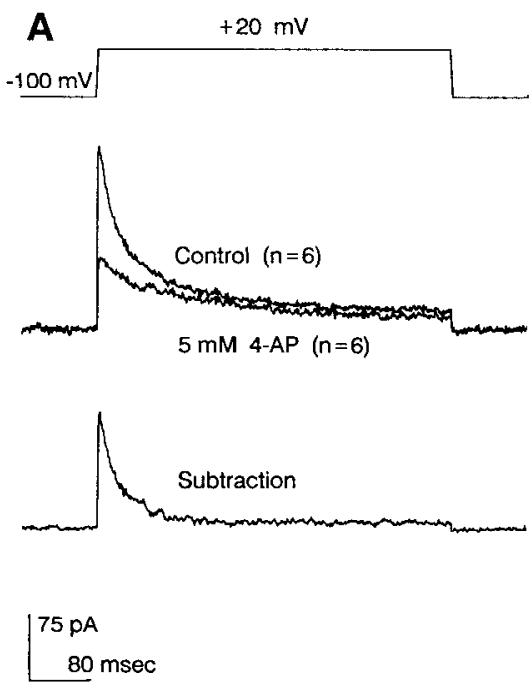

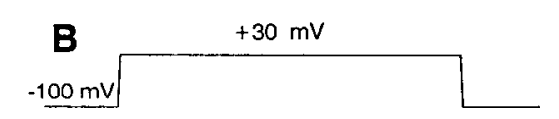
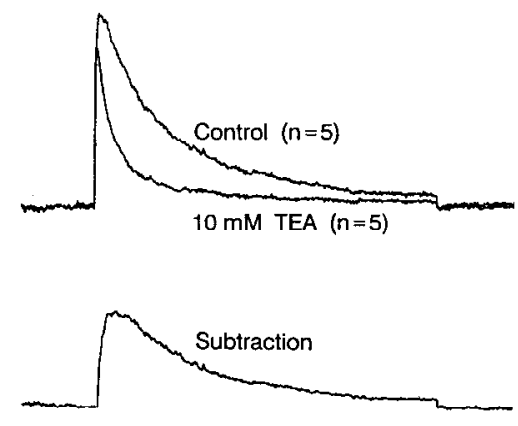

$100 \mathrm{pA}$
$100 \mathrm{msec}$
Figure 2. Sensitivity of wholc-ccll currents to externally applied 4-AP and $\mathrm{TEA}^{+} . A$, Effect of $5 \mathrm{~mm} 4$-AP on wholecell $\mathrm{K}^{+}$currents recorded at $+20 \mathrm{mV}$, $7 \mathrm{~d}$ culture. Top panel, Average of 6 traces before (larger current) and approximately $30 \mathrm{sec}$ after (smaller current) the introduction of $5 \mathrm{~mm} 4-\mathrm{AP}$ to the bath solution. The trace in the bottom panel is the difference between the current in control solution and the current in the presence of 4-AP. $B$, Effect of $10 \mathrm{mM} \mathrm{TEA}^{+}$on whole-cell $\mathrm{K}^{+}$currents recorded at $+30 \mathrm{mV}, 4 \mathrm{~d}$ culture. Top panel, Average of 5 traces before (larger current) and approximately $1 \mathrm{~min}$ after (smaller current) the introduction of $10 \mathrm{mM} \mathrm{TEA}^{+}$into the bath solution. Subtracted current is shown in the bottom panel. Averaged currents were used to show the time course of the drugsensitive components more accurately. The data were filtered at $4000 \mathrm{~Hz}(A)$ or $2000 \mathrm{~Hz}(B)$ and digitized at $0.8 \mathrm{msec} /$ point $(A)$ or $1 \mathrm{msec} /$ point $(B)$. appeared to be independent of voltage, but inward current (recorded negative to $0 \mathrm{mV}$ in standard solutions) was characterized by a rapid flicker. This channel appeared to be similar to the larger of the $2 \mathrm{Cl}^{-}$channels described by Yamamoto and Suzuki (1987), who attributed the rapid flicker to block by HEPES.

The heterogeneity of whole-cell currents in Drosophila CNS neurons facilitated the analysis of the gating behavior of some of these channels, since certain cells seemed to express primarily one channel type. The following sections present a more detailed analysis of the $A_{2}, K_{D}$, and $K_{1}$ channels both at the whole-cell and the single-channel levels.

\section{A channels}

Some cells, such as the one shown in Figure $1 A$, expressed primarily a fast transient whole-cell current. The current inactivated with a double-exponential time course largely independent of voltage, with time constants of 10-30 and 60-300 msec. In addition to its rapid inactivation, the current possessed properties characteristic of A-type potassium currents described in other preparations (Hagiwara et al., 1961; Connor and Stevens, 1971; Neher, 1971; see review by Rogawski, 1985): It was blocked by $5 \mathrm{~mm}$ 4-AP, activated at lower voltages than other currents in the cell, and was mostly inactivated by prepulses to $-50 \mathrm{mV}$.

In cell-free patch experiments, we have characterized a channel that, based on its kinetics and voltage dependence, can account for the properties of the whole-cell A current. We call this the $A_{2}$ channel to distinguish it from the $A_{1}$ channel, responsible for the A current in Drosophila muscle (Solc et al., 1987). Figure 4 shows single-channel current records from a patch that contained 2 active $A_{2}$ channels. The channels opened in response to depolarizing voltage steps, inactivated, and sometimes reopened later in the pulse. The records were selected for long openings with a low probability of overlapping events. Many of the apparent openings actually consist of bursts of repeated openings and closings with mean open and closed times of a few milliseconds, which can be resolved at higher filtering frequencies. This bursting behavior is apparent in the last opening of the top trace at $+10 \mathrm{mV}$, and the initial bursts in the bottom trace at $+30 \mathrm{mV}$. The mean open durations ranged from 2 to

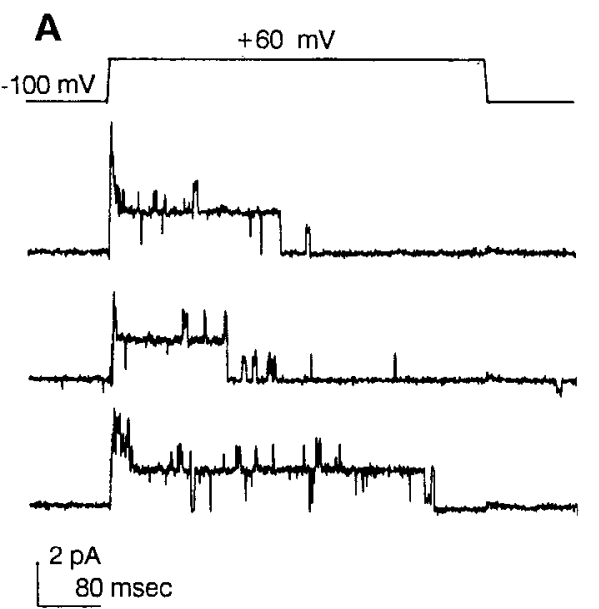

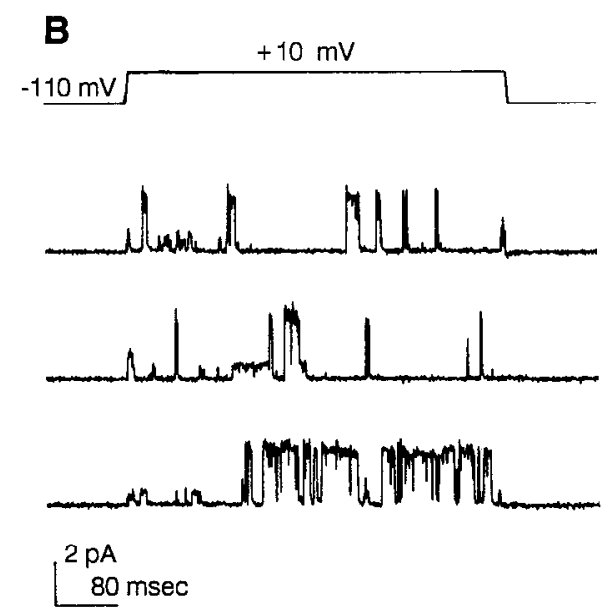

Figure 3. Outward currents through single channels recorded in outside-out patches from 2 different cells. $A$, Three current records during $480 \mathrm{msec}$ voltage steps from -100 to $60 \mathrm{mV}$. The patch contained at least 2 channel types: small transient channels and a larger more slowly inactivating channel. The small channels are seen most frequently at the beginning of the pulse but re-open throughout the voltage step. $B$, Same pulse protocol as in $A ; V_{P}=-110, V_{C}=$ $10 \mathrm{mV}$. This patch also contained at least 2 channel types: the small transient channels seen in $A$ and a larger channel distinct from the 2 inactivating channels. The data were filtered at 2000 $\mathrm{Hz}(A)$ or $1000 \mathrm{~Hz}(B)$ and digitized at $200 \mu \mathrm{sec} /$ point $(A)$ or $400 \mu \mathrm{sec} /$ point $(B)$. The records in $A$ were digitally filtered at $1000 \mathrm{~Hz}$ for display purposes. 
A

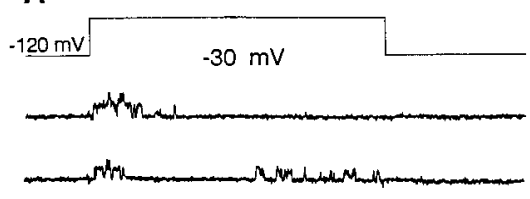

$-10 \mathrm{mV}$
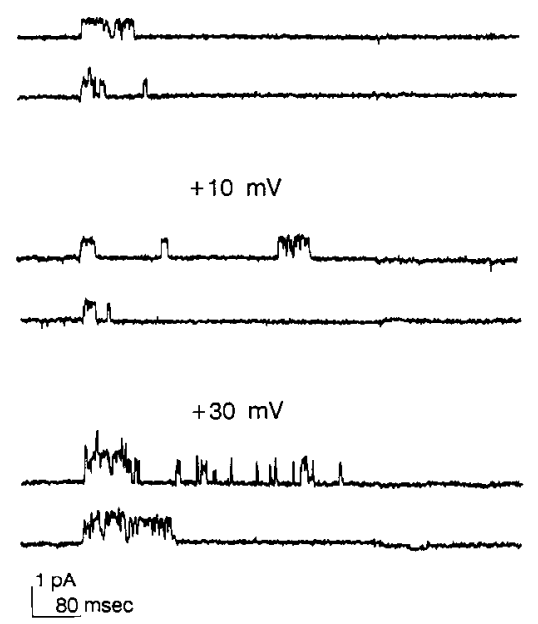

B

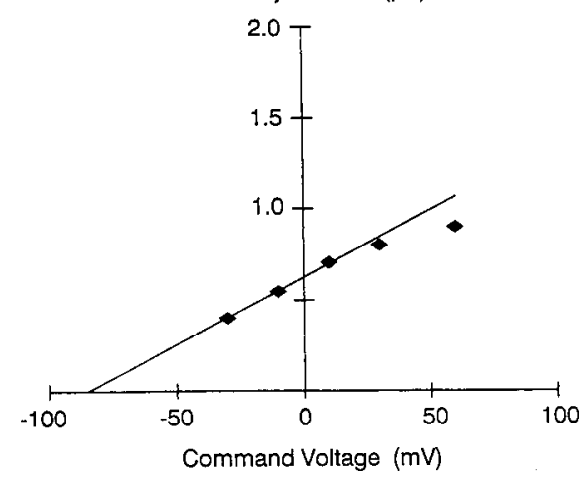

Figure 4. Single $\mathrm{A}_{2}$ channel currents. $A$, Currents during steps from $-120 \mathrm{mV}$ to each of 4 command voltages $(-30,-10,10,30 \mathrm{mV})$ from a patch that contained at least $2 \mathrm{~A}_{2}$ channels. The records were selected for low probability of overlapping openings. $B$, Single-channel currentvoltage relation for the $A$, channel. Current amplitude histograms were used to determine the unitary current at each voltage. A line fitted by eye to the data at low voltages has a slope of $7.3 \mathrm{pS}$ and a reversal potential of $-85 \mathrm{mV}$. The data were filtered at $1000 \mathrm{~Hz}$, digitized at $400 \mu \mathrm{sec} /$ point and digitally filtered at $500 \mathrm{~Hz}$. for display purposes.

$5 \mathrm{msec}$ and were not strongly voltage dependent. Current amplitude histograms of records with long openings were used to determine the unitary current amplitudes for the single-channel current-voltage relation $(I-V$; Fig. $4 B$ ). A linear fit to the data at low voltages gives a conductance of $7.3 \mathrm{pS} . \mathrm{A}_{2}$ channels in other patches ranged in conductance from 6 to $8 \mathrm{pS}$.

Ensemble averages of the $A_{2}$ channels inactivated with a time course similar to the whole-cell A current, indicating that some cells expressed mostly this channel type. Figure 5 shows ensemble averages of single $A_{2}$-channel currents and whole-cell $A$ currents at 4 command voltages on similar time scales. The rate of decay is adequately described by a sum of 2 exponentials with similar amplitudes and time constants of 10-20 and 60-
$100 \mathrm{msec}$. These rates varied somewhat from cell to cell both for whole-cell currents and for ensemble averages. The variability in inactivation rates at the whole-cell level is difficult to interpret because of the possible presence of both $A_{2}$ and $K_{D}$ channels, but different rates of decay of $A_{2}$-channel ensemble averages indicate that at least some of this variability can arise from different inactivation rates of $A_{2}$ channels. Single $A_{2}$ channels with both faster and slower inactivation than that shown in Figure 5 were observed (the ensemble averages in Fig. 7, for example, inactivate more slowly). In some patches, we also noticed a tendency for the ensemble average inactivation to get faster with time during the course of the experiment.

The inactivation of single $A_{2}$ channels by depolarizing prepulses agreed well with the prepulse inactivation of the wholecell $\mathrm{A}$ current. Figure 6 shows $\mathrm{A}_{2}$-channel currents recorded at $+30 \mathrm{mV}$ following prepulses to $-100,-60$, and -40 . This patch contained several $A_{2}$ channels. Voltage steps following prepulses to $-100 \mathrm{mV}$ generated many channel openings (Fig. $6 A$ ), prepulses to $-60 \mathrm{mV}$ inactivated some of the channels (Fig. $6 B$ ), and prepulses to $-40 \mathrm{mV}$ eliminated all of the singlechannel activity (Fig. $6 C$ ). The data from prepulses to -100 $\mathrm{mV}$ were recorded after the other runs to control for possible run-down of the channels. Figure 7 compares the prepulse inactivation of single $\mathrm{A}_{2}$ channels to that of the whole-cell $\mathrm{A}$ current. Figure $7, A$ and $B$, shows the effect of prepulses to a range of voltages on whole-cell A current recorded at $20 \mathrm{mV}$. A prepulse to $-100 \mathrm{mV}$ elicited a near-maximal response, while a prepulse to -50 inactivated over $95 \%$ of the current. The peak current normalized to current from $-100 \mathrm{mV}$ is plotted against the prepulse voltage in Figure $7 B$ and fitted with the following equation, derived from the Boltzmann distribution:

$$
I / I_{0}=1 /\left(1+\exp \left[\left(V-V_{1 / 2}\right) / S\right]\right)
$$

where $V=$ prepulse voltage, $V_{1 / 2}$ (midpoint of inactivation) $=$ $-73 \mathrm{mV}$, and $S$ (slope factor) $=6.9 \mathrm{mV}$. Figure $7 C$ shows ensemble averages of single $\mathrm{A}_{2}$-channel currents after prepulses to $-100,-80,-60$, and $-40 \mathrm{mV}$. Normalized integrals of these average currents are plotted as a function of prepulse voltage in Figure $7 D$. The data agree well with the prepulse inactivation of the peak whole cell A current (Fig. 7B). The points are superimposed with Equation $1\left(V_{1 / 2}=-74 \mathrm{mV}, S=7.2 \mathrm{mV}\right.$; values for $V_{1 / 2}$ and $S$ are mean values from 18 whole-cell experiments).

The voltage dependence of activation of whole-cell A current is shown in Figure 8. The current turned on with a sigmoid time course (Fig. $8 A$ ), especially apparent at low voltages, suggesting that the channels proceeded through at least 2 closed states before opening. At command voltages above $0 \mathrm{mV}$, the current peaked within 3-6 msec. The macroscopic activation rate was not significantly affected by varying the prepulse voltage between -140 and $-90 \mathrm{mV}$ (data not shown), suggesting that most of the channels occupied a similar distribution among the closed states at -90 and at $-140 \mathrm{mV}$. Figure $8 B$ shows the peak $I-V$ relation for the whole-cell A current in Figure $8 A$. The A current began to activate at lower voltages $(-45$ to $-40 \mathrm{mV})$ than the other components of outward current and increased linearly with voltage between -40 and $+30 \mathrm{mV}$. Tail currents recorded at $-120,-90,-75$, and $-60 \mathrm{mV}$, following $5 \mathrm{msec}$ pulses to $+40 \mathrm{mV}$, are shown in Figure $8 \mathrm{C}$. The tails decayed more rapidly at more negative voltages and reversed at approximately $-75 \mathrm{mV}$ in standard recording solutions (second trace from the top). The Nernst equilibrium potential for po- 

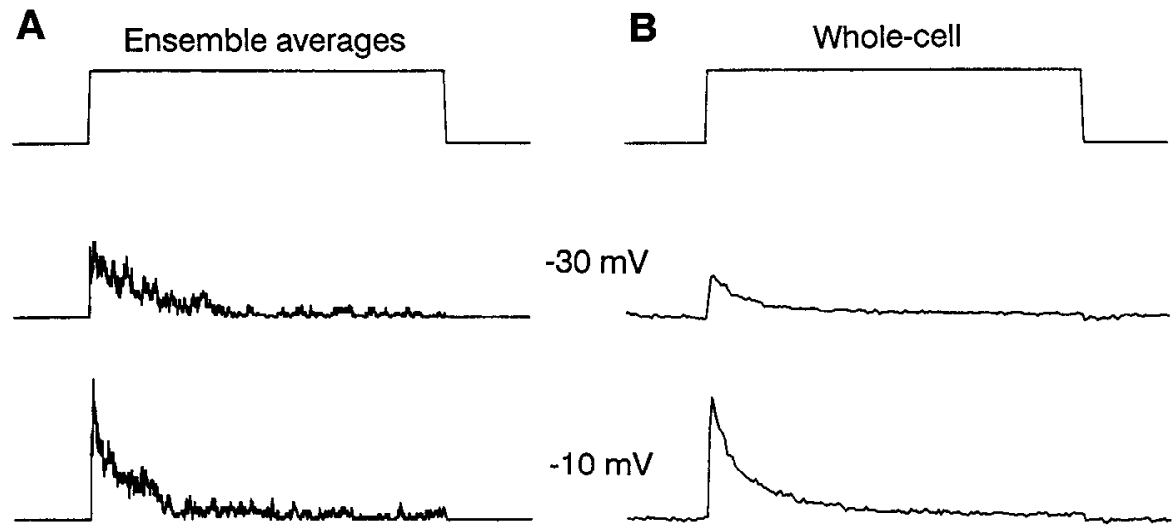

$-30 \mathrm{mV}$
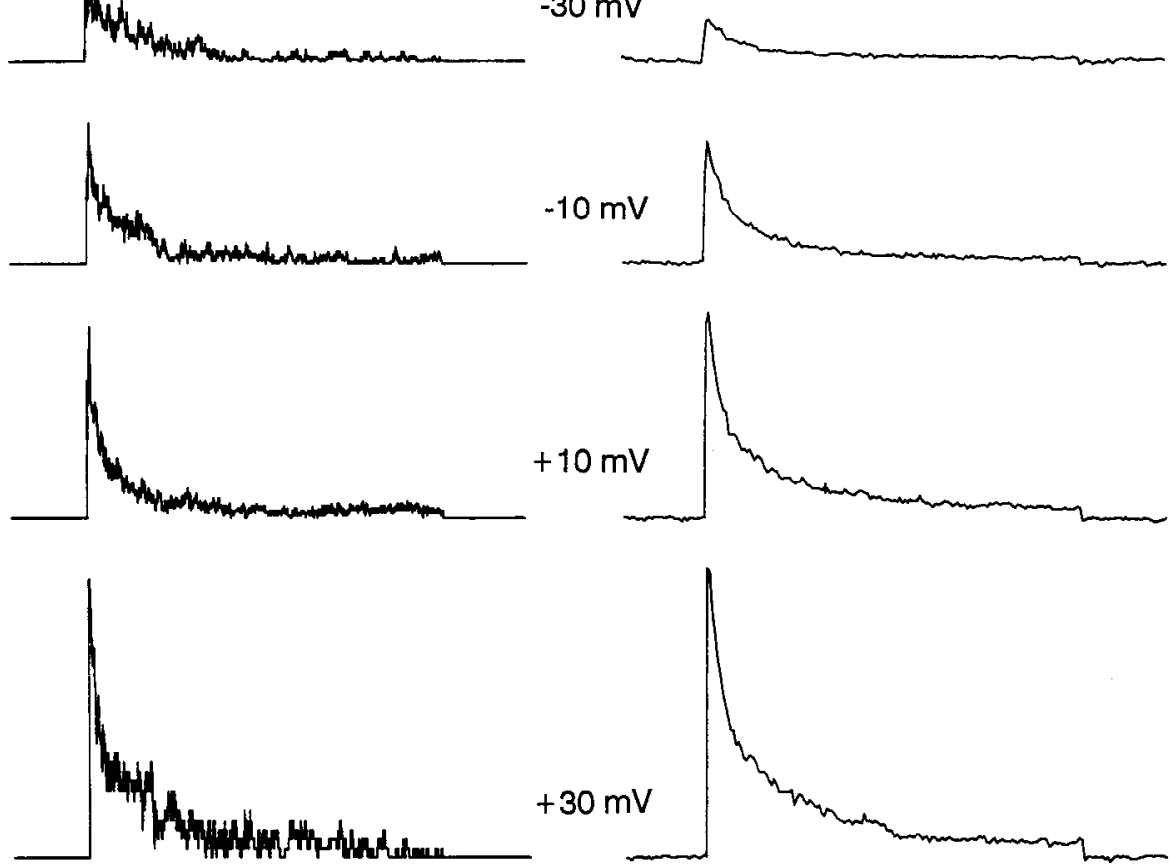

0.18
$80 \mathrm{msec}$

$80 \mathrm{pA}$

$75 \mathrm{msec}$

Figure 5. Ensemble averages of single $\mathrm{A}_{2}$ channel currents and whole-cell $\mathrm{A}$ currents. $A$, Ensemble averages of $21-$ 71 individual records from the experiment shown in Figure 4 at the same 4 command voltages. The vertical scale is the probability of a channel being open, assuming that there are 2 active channels in the patch. $B$, Whole-cell currents from the cell shown in Figure $1 A$ at the same command voltages. The whole-cell current decays with a time course similar to that of the ensemble averages.

tassium in these solutions is approximately $-100 \mathrm{mV}$, indicaling that the channels are not perfectly selective for potassium. Replacing the bath solution with a high- $\mathrm{K}^{+}$solution, however, shifted the current reversal potential to near $0 \mathrm{mV}$.

Single $A_{2}$ channels in outside-out patches were not obviously affected by 5 mm external 4-AP, $11 \mathrm{mM}$ external $\mathrm{TEA}^{+}, 1 \mathrm{mM}$ external $\mathrm{Cd}^{2+}, 20 \mathrm{~mm}$ external $\mathrm{Co}^{2+}$, or $0 \mathrm{~mm}$ external $\mathrm{Ca}^{2+}$. The lack of block by external 4-AP is in apparent contradiction to the effect of the drug on the whole-cell A currents (Fig. 2A) and is addressed in the discussion.

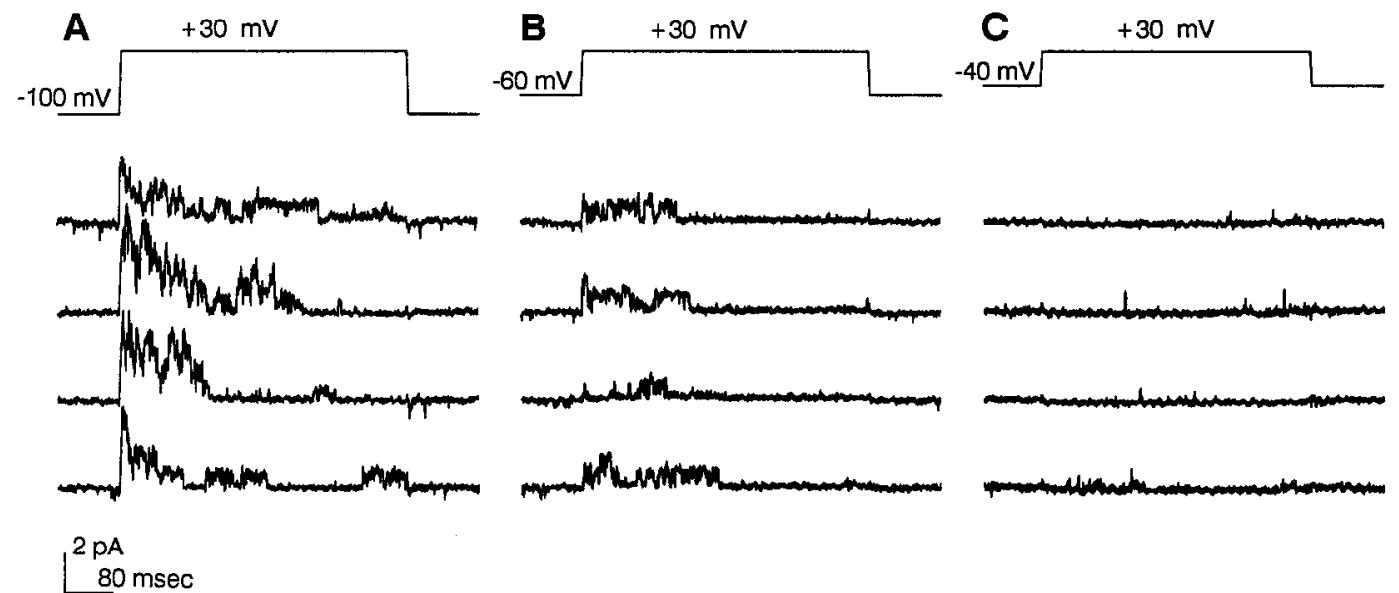

Figure 6. Prepulse inactivation of single $A_{2}$ channels. Four consecutive records at $+30 \mathrm{mV}$ from each of 3 prepulse voltages from a patch that contained several $\mathrm{A}_{2}$ channels. Current records from prepulses to $-100 \mathrm{mV}(A)$ have many openings, while records from prepulses to $-40 \mathrm{mV}$ (C) have virtually no openings. Records generated after prepulses to $-60 \mathrm{mV}$ have an intermediate amount of single-channel activity $(B)$. Order in which data were recorded during the experiment: $B, C, A$. The data were filtered at $1000 \mathrm{~Hz}$, digitized at $400 \mu \mathrm{sec} /$ point and digitally filtered at $750 \mathrm{~Hz}$ for display purposes. 
A
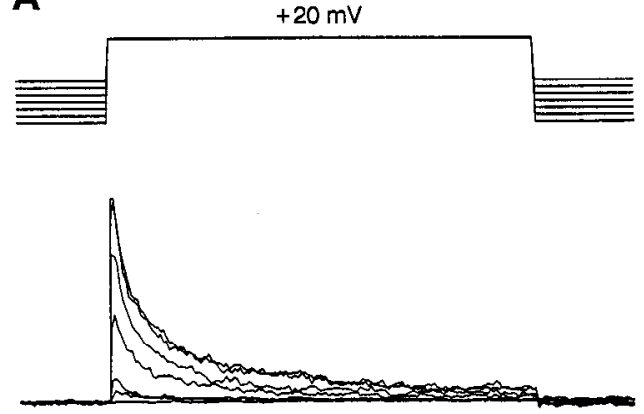

$100 \mathrm{pA}$
$75 \mathrm{msec}$

B

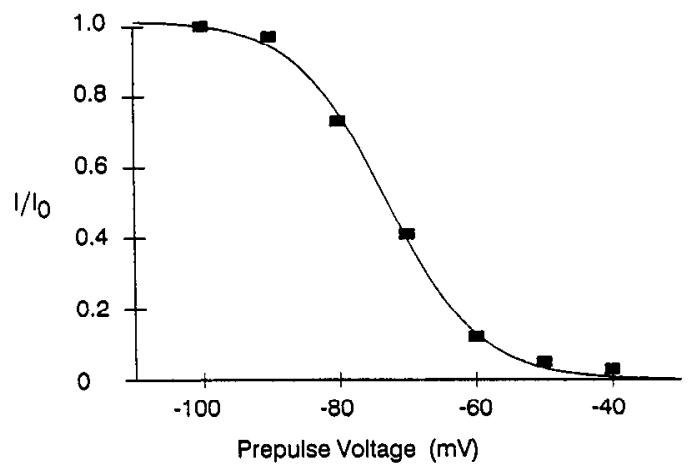

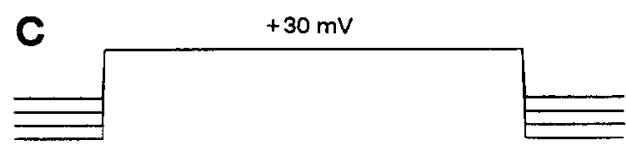

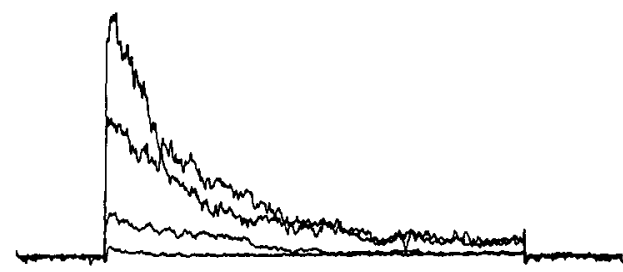

$1 \mathrm{pA}$
$80 \mathrm{msec}$

D

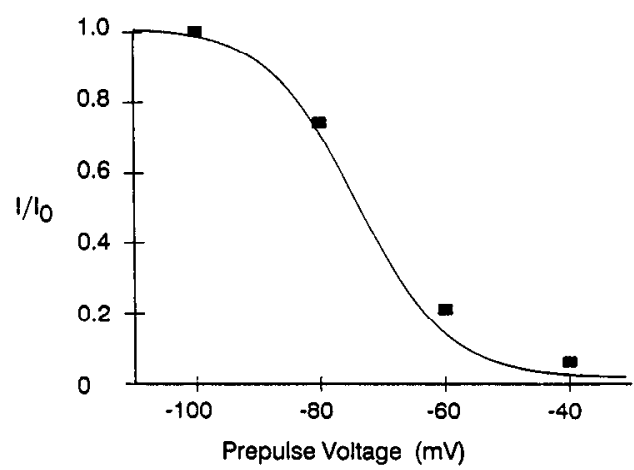

Figure 7. Prepulse inactivation of whole-cell A currents and $\mathrm{A}_{2}$-channel ensemble averages. $A$, Current family (same cell as in Fig. $1 A$ ) generated by steps to $20 \mathrm{mV}$ from a range of prepulse voltages $(-100$ to $-40 \mathrm{mV}$ in $10 \mathrm{mV}$ increments). The largest current corresponds to a prepulse of $-100 \mathrm{mV}$. Prepulse duration was $300 \mathrm{msec}$. $B$, Normalized peak current amplitudes plotted against the prepulse voltage ( $I$, current; $I_{0}$, current after $-100 \mathrm{mV}$ prepulse). The data are fitted with Equation $1\left(V_{1 / 2}=-73 \mathrm{mV}, S=6.7 \mathrm{mV}\right)$. $C$, Ensemble averages of $\mathrm{A}_{2}$-channel currents recorded at $30 \mathrm{mV}$ (same patch as in Fig. 6). The traces were generated by averaging 14-33 individual records from each of the 4 prepulse voltages. $D$, Integrals of the ensemble average currents normalized to the largest current and plotted against the prepulse voltage. The data are superimposed with Equation $1\left(V_{1 / 2}=-74 \mathrm{mV}, S=7.2 \mathrm{mV}\right.$; values equal to the means from 18 whole-cell A current experiments). The whole-cell data were filtered at $2000 \mathrm{~Hz}$ and digitized at $3 \mathrm{msec} /$ point.

\section{$K_{D}$ channels}

A transient component of outward whole-cell current with slower activation and inactivation kinetics than the $A$ current was evident in many of the cells studied. We did not, however, observe this component isolated in an individual cell to the extent described for the A current. Indeed, based on prepulse inactivation and whole-cell activation kinetics, the slower component was present along with at least some A current in all of the cells that expressed it. In some cases, however, the midpoint
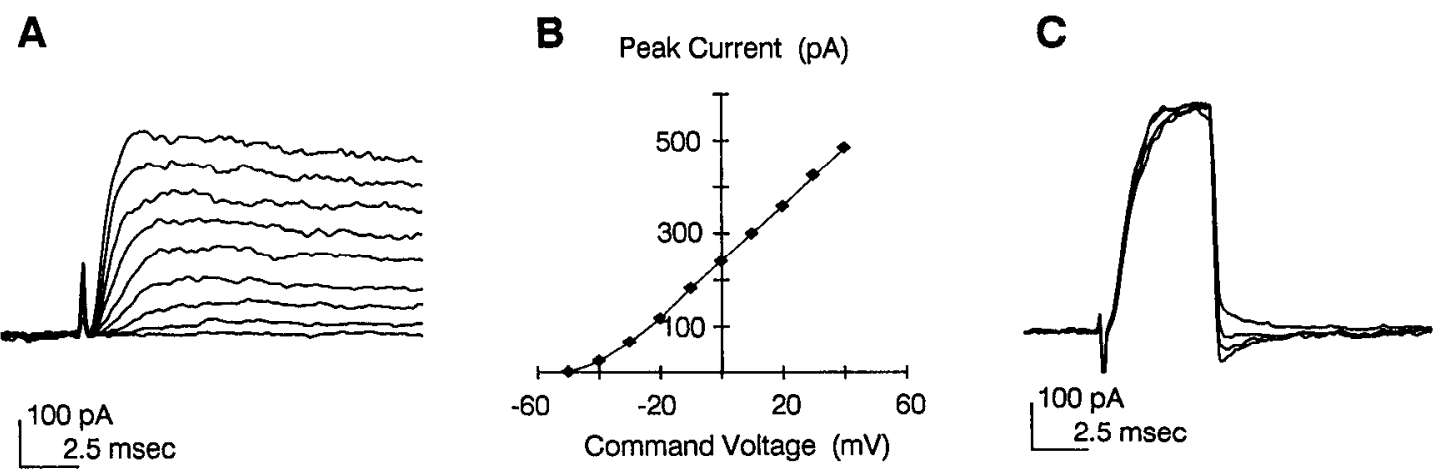

Figure 8. Activation and deactivation of A currents. $A$, Currents recorded during $15 \mathrm{msec}$ steps, $V_{P}=-100 \mathrm{mV}, V_{C}=-50-30 \mathrm{mV}$ in $10 \mathrm{mV}$ increments. $B$, Peak current-voltage relation for the currents shown in $A$. $C$, Tail currents from a different cell that was expressing primarily $\mathrm{A}$ current. The voltage was stepped to $+40 \mathrm{mV}$ for $5 \mathrm{msec}$ from a prepulse voltage of $-90 \mathrm{mV}$ and then returned to different postpulse voltages. The tail currents shown were elicited at postpulse voltages of $-120 \mathrm{mV}$ (bottom trace), $-90,-75$, and $-60 \mathrm{mV}$. The currents reverse at $-75 \mathrm{mV}$. The data were filtered at $2000 \mathrm{~Hz}$ and digitized at $100 \mu \mathrm{sec} /$ point. 

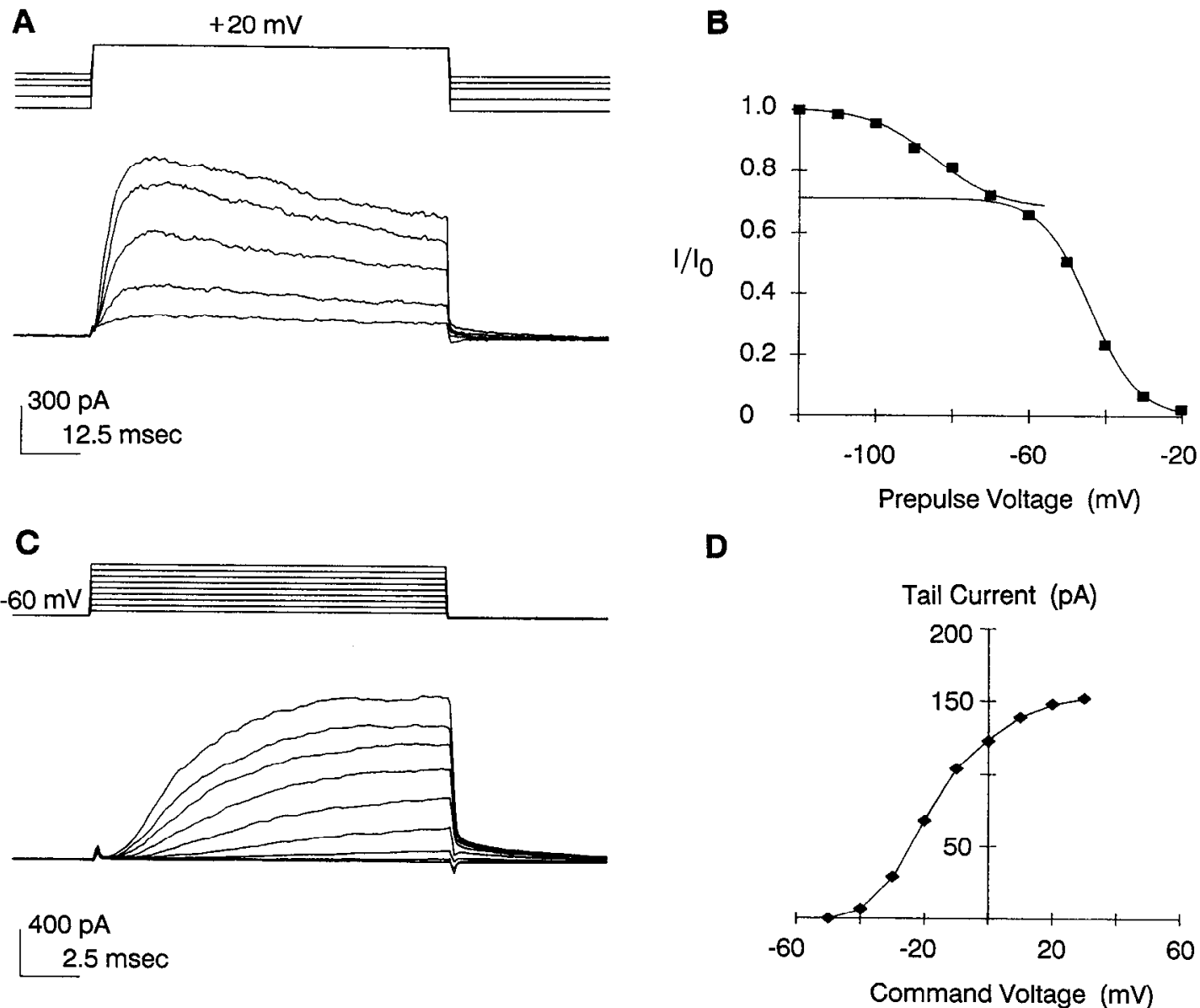

Figure 9. Separation of 2 components of $\mathrm{K}^{+}$current by depolarizing prepulses. $A$, Currents from the cell shown in Figure $1 B$ during $75 \mathrm{msec}$ steps to $20 \mathrm{mV}$ from a range of prepuise voltages $(-90,-70,-50,-40$, and $-30 \mathrm{mV}) . B$, Normalized peak current shown in $\mathrm{A}$ plotted as a function of the prepulse voltage. The data are fitted with a sum of 2 distributions given by Equation 1 . Approximately $30 \%$ of the current was inactivated by prepulses to $-65 \mathrm{mV}$ and is fitted with Equation $1\left(S=8.5 \mathrm{mV}, V_{1 / 2}=-85 \mathrm{mV}\right)$. Most of the remaining current inactivated with a more positive prepulse inactivation curve $\left(S=6.3 \mathrm{mV}, V_{1 / 2}=-44 \mathrm{mV}\right)$. The data shown in this panel were adjusted for experimental run-down using linear interpolation between records at identical voltages during the course of the experiment. $C$, Currents from same cell during $15 \mathrm{msec}$ steps, $V_{P}=$ $-60 \mathrm{mV}, V_{c}=-50-30 \mathrm{mV}$. Note the outward tail currents at the end of the voltage step. The magnitude of these tail currents, measured 1 msec after the end of the voltage step, is plotted against the command potential in $D$. The data were filtered at $2000 \mathrm{~Hz}$ and digitized at $500 \mu$ sec/point (A) or $100 \mu \mathrm{sec} /$ point $(C)$.

of the prepulse inactivation curve $\left(V_{1 / 2}\right)$ of this component was $30-40 \mathrm{mV}$ more positive than the $V_{1 / 2}$ of the A current, and the slower component could be isolated by applying depolarizing prepulses.

Currents from such a cell are shown in Figure 9. The currents were recorded at $+20 \mathrm{mV}$ from a range of prepulse voltages (Fig. 9A). The data are fitted with a sum of 2 Boltzmann distributions with midpoints of $-85 \mathrm{mV}(32 \%)$ and $-44 \mathrm{mV}(68 \%)$ (Fig. $9 B$ ). These results are consistent with the idea that 2 channel populations were contributing to the whole-cell current. $A_{2}$ channels were responsible for the component that inactivated at the low voltages, while a different class of channels $\left(K_{D}\right.$ channels) was responsible for the component that inactivated at the more positive voltages. The activation time course of the latter component, isolated by applying prepulses to $-60 \mathrm{mV}$ (Fig. $9 \mathrm{C}$ ) was slower than the activation time course of A current (Fig. $8 A$ ). The slower currents also began to activate at slightly higher voltages than the A current. The degree of activation as a function of command voltage is illustrated using tail currents, which reflect the conductance activated at the end of the command voltage steps. The tail current magnitude is plotted against the command voltage in Figure 9D. The curve gives a good indication of the voltage-dependence of activation at higher voltages, but the amount of activation at the lower voltages is slightly underestimated since the current had not reached its peak during the 15 msec pulses.

Single $\mathrm{K}_{\mathrm{D}}$ channels in cell-free patches had kinetic properties similar to the slowly activating and inactivating component of whole-cell current. The channels opened and inactivated more slowly, were larger, and had longer open times than the $A_{2}$ channels (Fig. 10, top). Because channel openings were often interrupted by very brief closures, the open times were influenced by the filter and sampling frequencies. Mean open durations obtained from records filtered and sampled at $1000 \mathrm{~Hz}$ ranged from $5-15 \mathrm{msec}$ at $-20 \mathrm{mV}$ to $30-50 \mathrm{msec}$ at $+30 \mathrm{mV}$. Sweeps with channel openings were often clustered in time separated by sweeps without openings (data not shown). This effect was minimized by applying negative prepulses, indicating the presence of a voltage-dependent slow inactivation process. The inactivation time course of the ensemble averages (Fig. 10, bottom) varied considerably from patch to patch, ranging from $\hat{i} 00$ to $1200 \mathrm{msec}$. At higher voltages $(+20$ to $+50 \mathrm{mV})$, the prob- 


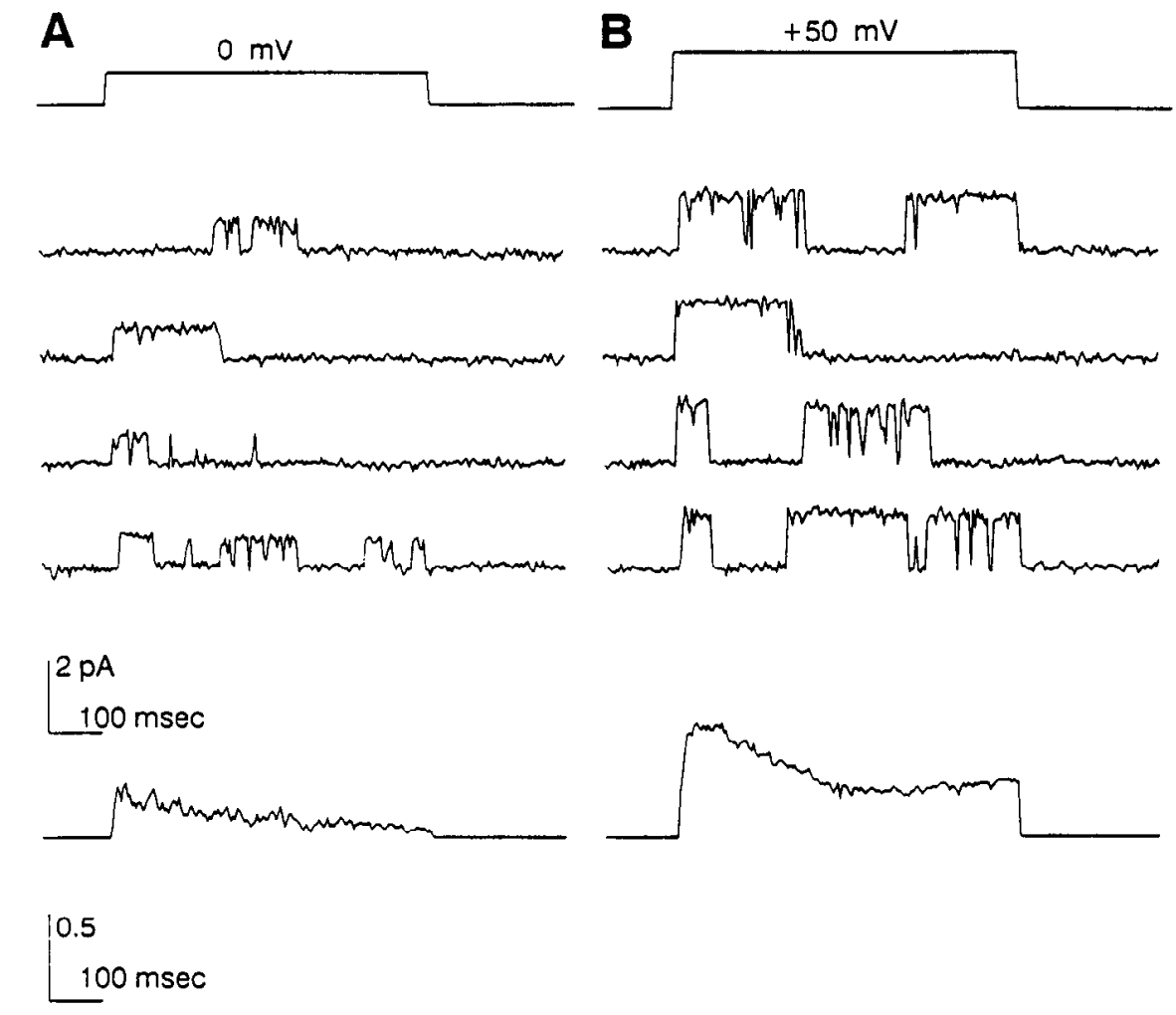

Figure 10. Single $\mathrm{K}_{\mathrm{D}}$-channel currents and their ensemble averages. Four single-channel records (upper part) generated by steps to $0 \mathrm{mV}(A)$ and +50 $\mathrm{mV}(B)$ from $-90 \mathrm{mV}(A)$ and $-80 \mathrm{mV}$ (B). Prepulse duration was $300 \mathrm{msec}$, command pulse duration was $450 \mathrm{msec}$. Ensemble averages, each constructed from 64 traces at the same 2 voltages is shown in the lower part of the figure. The data were filtered at $2000 \mathrm{~Hz}$ and digitized at $4 \mathrm{msec} /$ point. ability of the channel being open late in the pulse was consistently larger than at lower voltages. The activation time course of the $\mathrm{K}_{\mathrm{D}}$ channels is shown in Figure 11. Ensemble averages during $15 \mathrm{msec}$ pulses (Fig. 11A) activated with a time course similar to whole-cell currents from the cell in Figure 9 at the same voltages (Fig. 11B).

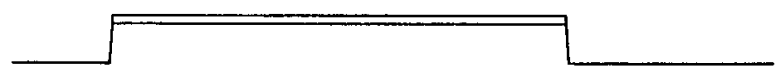

A

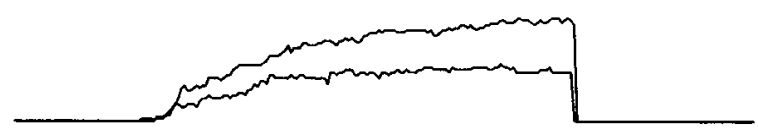

0.5

$2.5 \mathrm{msec}$

B

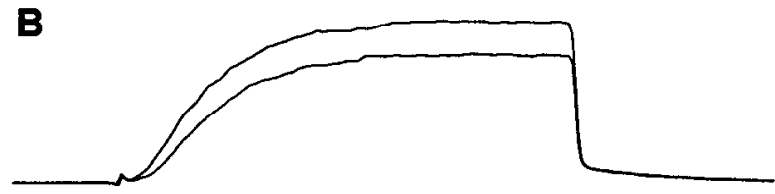

$600 \mathrm{pA}$

$2.5 \mathrm{msec}$

Figure 11. Activation of $\mathrm{K}_{\mathrm{D}}$-channel ensemble averages and wholecell currents. $A, \mathrm{~K}_{\mathrm{D}}$-channel ensemble averages during $15 \mathrm{msec}$ steps to +40 and $+60 \mathrm{mV}$ from a $300 \mathrm{msec}$ prepulse to $-60 \mathrm{mV}$. $B$, Wholecell currents recorded from the same cell as shown in Figure $1 B$ and 9 with the same prepulse and command voltages.
$\mathrm{K}_{\mathrm{D}}$ single-channel currents in response to voltage ramps between -100 and $+100 \mathrm{mV}$ are shown in Figure 12. In standard solutions (Fig. 12A, top trace), the channel began to open at $-45 \mathrm{mV}$ and continued to open and close for the duration of the ramp. The records were leak-subtracted so that the current while the channel was closed is horizontal. The slope of the inclined line (fitted to the open state of the channel) is cqual to the single-channel conductance $(14 \mathrm{pS})$, and the intercept is equal to the reversal potential $(-69 \mathrm{mV}) . \mathrm{K}_{\mathrm{D}}$ channels from different patches ranged in conductance between 10 and $16 \mathrm{pS}$, and occasionally exhibited sojourns to subconductance states of $30-70 \%$ of the single-channel amplitude (for example, Fig. $12 A$, top trace, closed event near $0 \mathrm{mV}$ ).

Figure 12 also illustrates the $\mathrm{K}^{+}$selectivity and TEA' sensitivity of the $K_{D}$ channel. Upon replacement of the bath solution with one containing $140 \mathrm{mM} \mathrm{K}^{+}$, the reversal potential shifted to $0 \mathrm{mV}$ (Fig. $12 A$, middle trace). The high external $\mathrm{K}^{+}$concentration introduced inward rectification into the open-channel $I-V$ and increased the conductance to $32 \mathrm{pS}$ for inward current and $20 \mathrm{pS}$ for outward current. The $\mathrm{K}_{\mathrm{D}}$ channel was sensitive to $\mathrm{TEA}^{+}$(Fig. 12B). Bath application of $11 \mathrm{mM} \mathrm{TEA}^{+}$reduced the apparent single-channel conductance from 14 to $4 \mathrm{pS}$ (Fig. $12 \mathrm{~B}$, middle trace), which is consistent with a fast open-channel block mechanism of action (see Coronado and Miller, 1979): $\mathrm{TEA}^{+}$enters, blocks, and leaves the pore with rates much faster than our recording frequency such that the single-channel current amplitude reflects the fraction of time that the channel is blocked. The fact that this reduced current increased linearly with voltage, like the control current, suggests that TEA ${ }^{+}$block of this channel was not strongly voltage dependent between -40 and $+100 \mathrm{mV}$. The inactivation time course and block by TEA ${ }^{+}$ of the $\mathrm{K}_{\mathrm{D}}$ channel support the idea that this channel underlies the slowly inactivating $\mathrm{TEA}^{+}$-sensitive component of whole-cell 

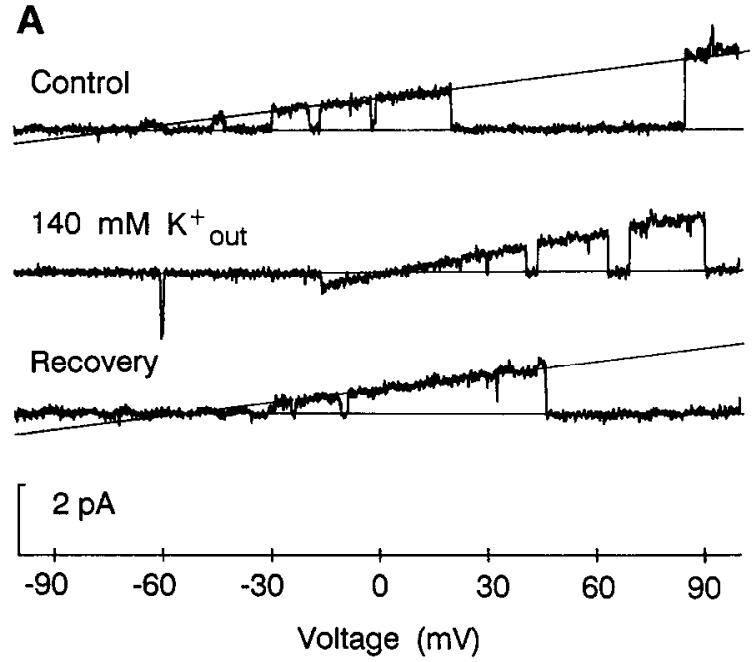

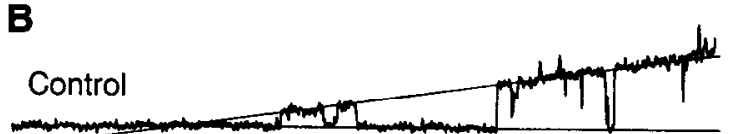

$$
10 \mathrm{mM} \text { TEA }^{+} \text {out }
$$
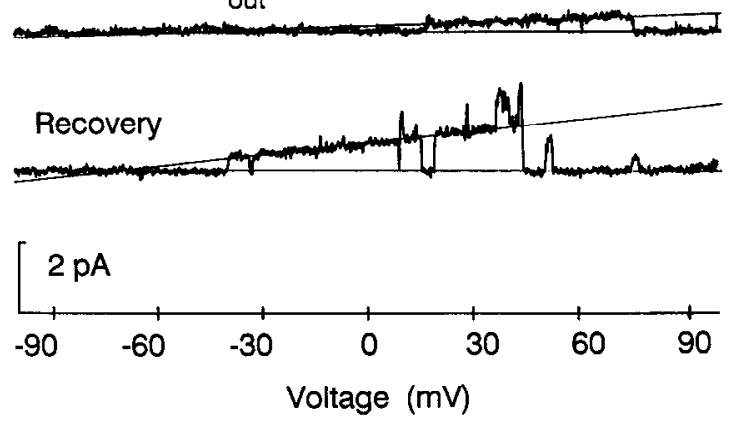

Figure 12. Voltage-ramp records from a patch that contained a single $\mathrm{K}_{\mathrm{D}}$ channel in control (top traces), $140 \mathrm{~mm}$ external $\mathrm{K}^{+}(A$, middle trace), and $11 \mathrm{~mm}$ external TEA ${ }^{+}(B$, middle trace) solutions. The membrane voltage was ramped at $0.8 \mathrm{mV} / \mathrm{msec}$ between -100 and $+100 \mathrm{mV}$. The straight lines follow the open and closed states of the channel and give the single-channel conductance and reversal potential. $A$, In control solutions, the channel started to open at about $-45 \mathrm{mV}$ and had a linear single-channel current-voltage relation with a conductance of $14 \mathrm{pS}$ and a reversal potential of $-69 \mathrm{mV}$. In symmetrical $\mathrm{K}^{+}$solutuions, the reversal potential shifted to approximately $0 \mathrm{mV}$ and the single-channel conductance increased to $32 \mathrm{pS}$ for inward current and $20 \mathrm{pS}$ for outward current. $B$, External TEA ${ }^{+}, 11 \mathrm{mM}$, reversibly reduced the apparent single-channel conductance to approximately $4 \mathrm{pS}$. The patch also contained at least one $\mathrm{A}_{2}$ channel, which can be seen in the bottom trace in $B$. The data were filtered at $1000 \mathrm{~Hz}$, digitized at $400 \mu \mathrm{sec} /$ point, and digitally filtered at $500 \mathrm{~Hz}$ for display purposes.

current (Fig. 2B). Externally applied 5 mm 4-AP had no obvious effect on these channels.

The voltage dependence of prepulse inactivation of $\mathrm{K}_{\mathrm{D}}$ channels was variable. Figure 13 shows ensemble averages of $2 K_{D}$ channels, one that had a negative prepulse inactivation curve (Fig. 13A) and one that began to inactivate at higher voltages (Fig. $13 B$ ). The average open probability $\{P(0)\}$ during the test pulse, normalized to the peak $P(0)$, is plotted against the prepulse
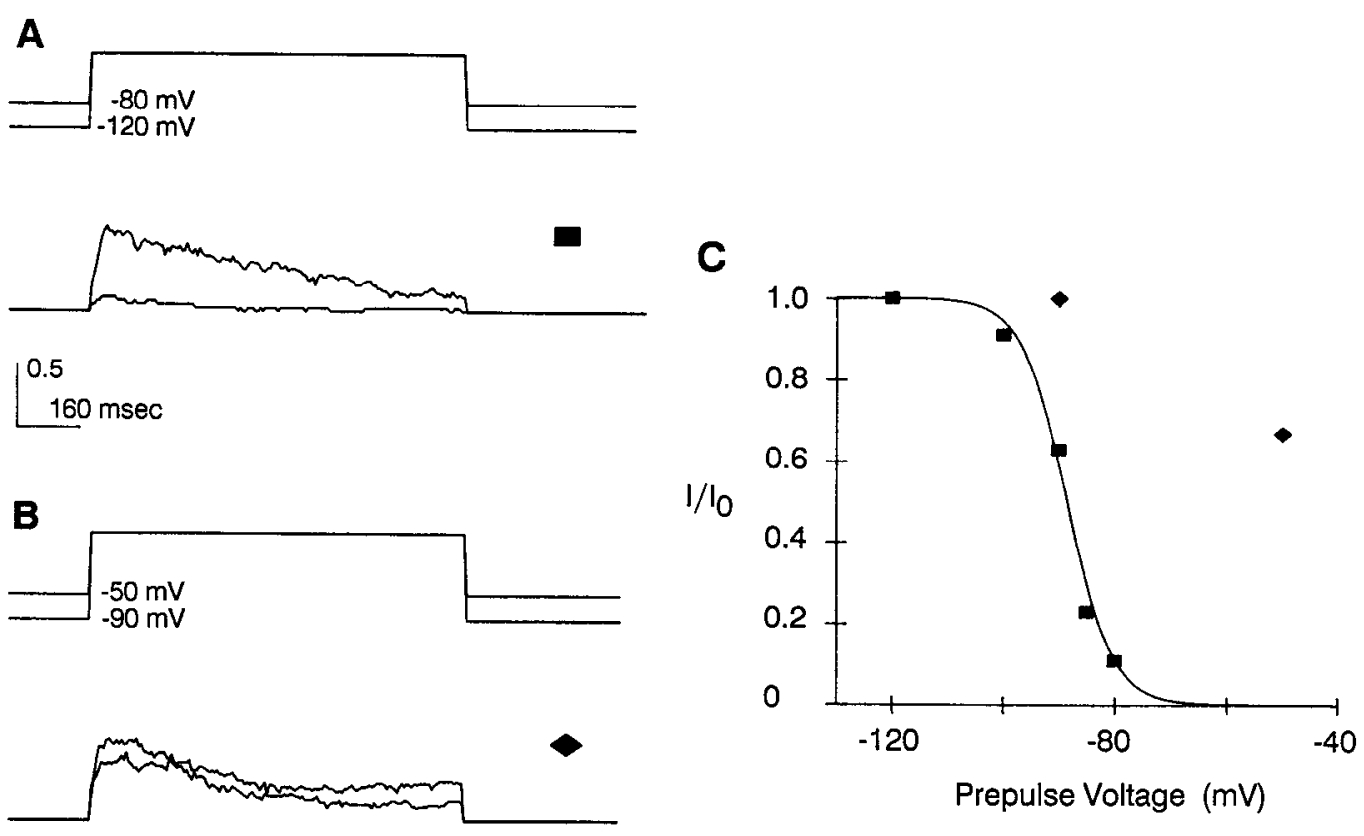

Prepulse Voltage (mV)

0.5

$100 \mathrm{msec}$

Figure 13. Prepulse inactivation of $\mathrm{K}_{\mathrm{D}}$-channel ensemble averages. The voltage dependence of prepulse inactivation was variable from patch to patch. $A$, Ensemble averages of a $\mathrm{K}_{\mathrm{D}}$ channel during $960 \mathrm{msec}$ voltage steps to $0 \mathrm{mV}$ from a prepulse to $-120 \mathrm{mV}$ (larger trace) and from a prepulse to $-80 \mathrm{mV}$ (smaller trace). $B$, Ensemble averages of a different $\mathrm{K}_{\mathrm{D}}$ channel (same channel as in Fig. 10) during $600 \mathrm{msec}$ voltage steps to $50 \mathrm{mV}$ from prepulses to $-90 \mathrm{mV}$ (larger trace) and $-50 \mathrm{mV}$ (smaller trace). $C$, Normalized average $P(0)$ of channels in $A$ (squares) and $B$ (diamonds) plotted against the prepulse voltage. The values were normalized to the $P(0)$ after a prepulse to $-120 \mathrm{mV}$ for the data in $A(0.37)$ and after a prepulse to $-90 \mathrm{mV}$ for the data in $B(0.35)$. The (square) symbol at $-120 \mathrm{mV}$ is actually 2 superimposed data points, one from the first run in the set and the other from the last, illustrating the stability of the preparation during the experiment. The data from $A$ are fitted with Equation 1 $\left(V_{1 / 2}=-88 \mathrm{mV}, S=4 \mathrm{mV}\right)$. 
A

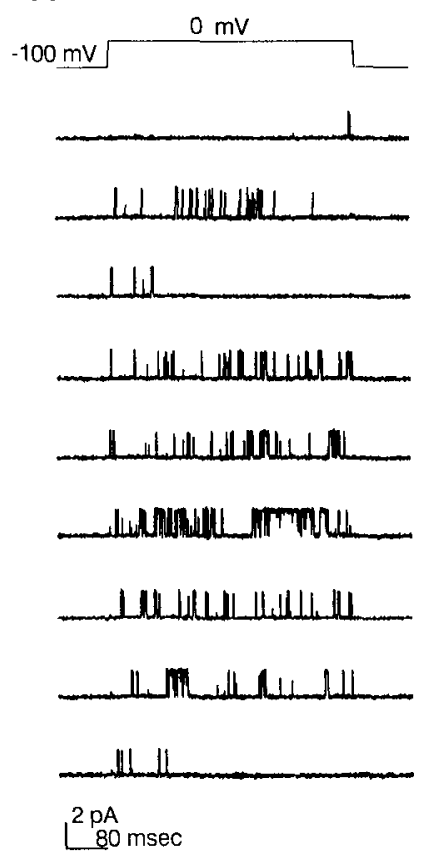

B
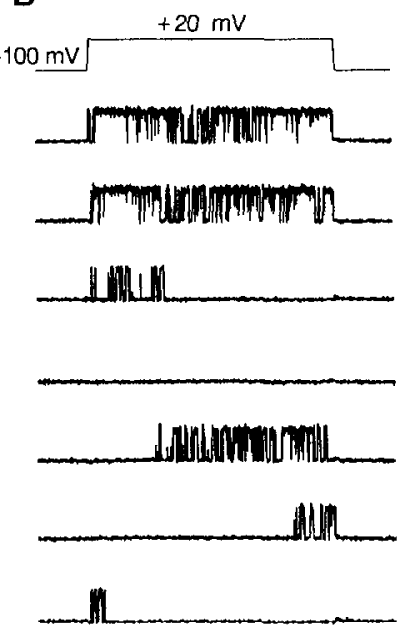

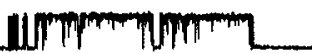

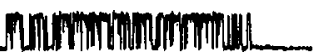

C

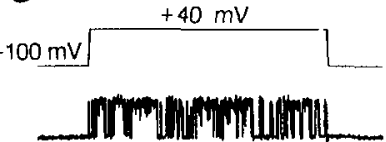

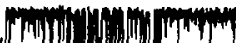

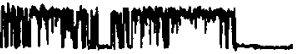

Minmulam

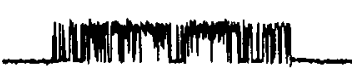

Uก:

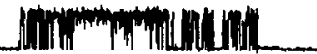

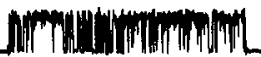

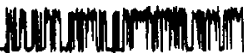
$\mathrm{mV}$ to $0 \mathrm{mV}$ (left column), (center column), or column), $+20 \mathrm{mV}$ $u m n$ ). The data were filtered at 1000 $\mathrm{Hz}$ and digitized at $400 \mu \mathrm{sec} /$ point.

voltage in Figure $13 C$. The data for the channel with the more negative prepulse inactivation curve (Fig. 13A) are fitted with Equation $1\left(V_{1 / 2}=-88 \mathrm{mV}, S=4 \mathrm{mV}\right)$. To control for experimental run-down, averages from a prepulse to -120 were recorded at the start of the experiment and again at the end of the experiment. The $P(0)$ was identical for the 2 averages $(0.37)$. Prepulses to $-80 \mathrm{mV}$ almost completely inactivated this channel, while the channel illustrated in Figure $13 B$ exhibited very little inactivation in this voltage range. We do not know what accounts for this variability. It was not correlated with time after patch excision, nor was it due to a simple shift in the patch pipette voltage, as the 2 channel types activated in the same voltage range and had similar conductances and reversal potentials.

The variability in prepulse inactivation of the slower component of current was also observed at the whole-cell level. Many cells expressed $\mathrm{K}^{+}$currents that inactivated relatively slowly but had a prepulse inactivation curve similar in slope and midpoint to that observed for the A current (Fig. 7). In cases where the activation of the current was also slow (as in Fig. $1 B$, for example), the current was likely due in large part to $K_{D}$ channels with a negative prepulse inactivation curve. In cases where the activation of the whole-cell current was rapid, however, the current may have been due to a combination of $A_{2}$ and $K_{D}$ channels or simply to slowly inactivating $A_{2}$ channels.

\section{$K$ channels}

The third component of whole-cell current (seen rarely in isolation) was a sustained current. The sustained currents showed no appreciable inactivation during $500 \mathrm{msec}$ voltage steps, suggesting that channels other than the $A_{2}$ and the $K_{D}$ channels were instrumental in the whole-cell current response. We have observed several $\mathrm{K}^{+}$channels that did not show a decline in open probability during $500 \mathrm{msec}$ voltage steps. Of these, the $\mathrm{K}_{1}$ channel was the most common and most readily studied.

The $\mathrm{K}_{1}$ channels started to activate at approximately $-20 \mathrm{mV}$ and opened in bursts with complex gating behavior (Fig. 14). Open and burst duration histograms were fitted with 2 expo- nentials, while closed duration histograms required at least 3 exponential components for an adequate fit. The voltage dependence of mean open and closed durations resulted in an increased probability of being open at higher voltages (Fig. 15A). However, although the $\mathrm{P}(0)$ increased for any given channel with voltage, the absolute values varied considerably from patch to patch. The values shown in Figure $15 A$ are higher than average.

The single-channel $I-V$ relation for $\mathrm{K}_{1}$ channels from 2 patches is shown in Figure $15 B$. At voltages above $0 \mathrm{mV}$, a linear fit gives a unitary conductance of $37 \mathrm{pS}$. The $K_{1}$ channels had the most variable single-channel conductance from patch to patch, ranging from 20 to $40 \mathrm{pS}$ In most patches, the unitary current through the $K_{1}$ channels fluctuated substantially more than the unitary current of the other channel types.

Ensemble averages during $450 \mathrm{msec}$ pulses compared well to whole-cell currents at the same voltages (Fig. 16). Although the ensemble averages did not inactivate on this time scale, the frequency of observing blank sweeps increased with more depolarized prepulses. The clustering of blank sweeps (evident in Fig. 14B) and the long (seconds) closed durations seen during steady-state recording (data not shown) indicate the presence of a slow inactivation process. Indeed, whole-cell sustained currents were also decreased by depolarizing prepulses but had a less well-defined prepulse inactivation curve than the other components of current.

\section{Discussion}

Potassium currents in larval Drosophila CNS neuronal somata can have at least 3 components: a fast transient component (A current), a more slowly inactivating component, and a noninactivating component. The relative amount of each component differs from cell to cell, resulting in a range of whole-cell current patterns (Fig. 1), a phenomenon observed in many molluscan neurons (Aldrich et al., 1979; Byerly and Moody, 1986). Cellfree patch experiments demonstrated the existence of at least 3 distinct $\mathrm{K}^{+}$channels activated by depolarizing voltage steps: $\mathrm{A}_{2}$ 

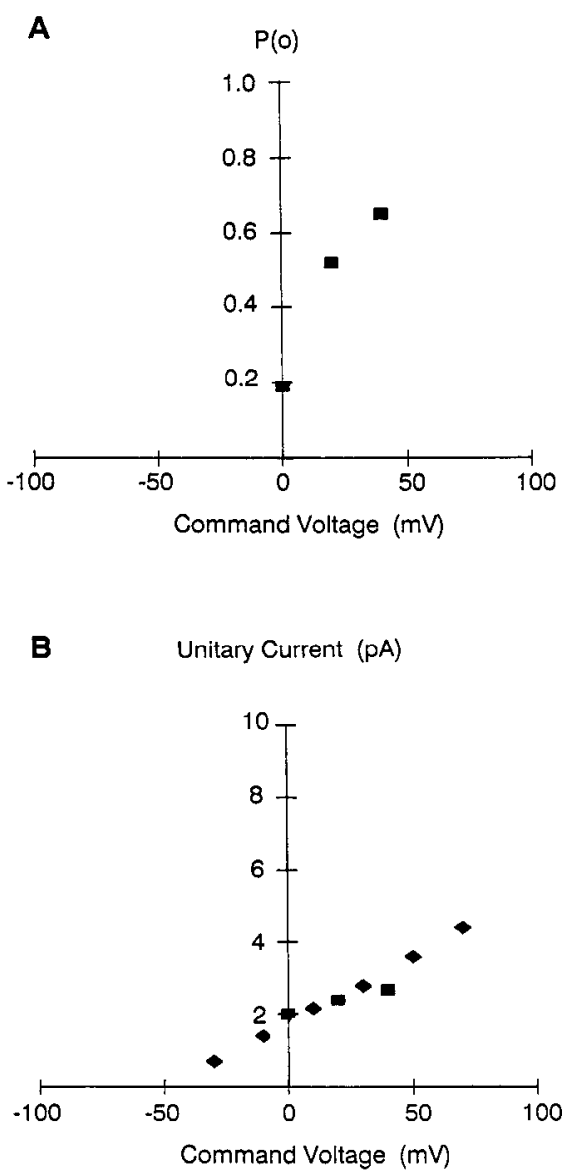

Figure 15. A, Probability of the $\mathrm{K}_{1}$ channel (shown in Fig. 14) being open as a function of the command voltage. $B$, Single-channel $I-V$ relation for $\mathrm{K}_{1}$ channels from 2 different patches. Squares are data points for the channel in Figure 14

channels, $K_{D}$ channels, and $K_{1}$ channels (Fig. 3). Although we sometimes observed other $\mathrm{K}^{+}$channel types, these 3 channels, based on their voltage dependence and gating kinetics, are sufficient to account for the current patterns observed in the wholecell configuration.

We did not observe voltage-dependent $\mathrm{Na}^{+}$currents in any of the cells studied (1-12 d cultures, various cell morphologies). Previous work, however, suggests that $\mathrm{Na}^{+}$channels are present in the same preparation at the same culture ages, bascd on veratradine-induced cell death, and the block of veratradineinduced cell death by tetrodotoxin (Wu et al., 1983b). One possible explanation is that the $\mathrm{Na}^{+}$channels are confined to the neuronal processes in 1-12 d cells and cannot be revealed by whole-cell clamp of the soma.

The single $\mathrm{K}^{+}$channels characterized in this study did not require elevated internal calcium for the observed gating. We have, however, occasionally recorded slowly inactivating outward currents that can be blocked by $1 \mathrm{~mm}$ external $\mathrm{Cd}^{2+}$ and that have an $\mathrm{N}$-shaped $I-V$ relation. Both the $\mathrm{Cd}^{2+}$ block and the $\mathrm{N}$-shaped $I-V$ are distinguishing features of $\mathrm{K}^{+}$currents activated by $\mathrm{Ca}^{2+}$ influx through voltage-activated $\mathrm{Ca}^{2+}$ channels (see review by Adams et al., 1980) and suggest that $\mathrm{Ca}^{2+}$ channels, as well as $\mathrm{Ca}^{2+}$-dependent $\mathrm{K}^{+}$channels, may be present in these cells.

Voltage-clamp studies of larval and pupal Drosophila muscle (Salkoff and Wyman, 1981a; Salkoff, 1983; Wu et al., 1983a) have identified 3 major components of $\mathrm{K}^{+}$currents: a fast transient A current, a delayed current and a $\mathrm{Ca}^{2+}$-dependent fast transient current. Recently, the presence of an additional $\mathrm{Ca}^{2+}-$ dependent $\mathrm{K}^{+}$current has been reported (Wei and Salkoff, 1986). Komatsu et al. (1986) reported 5 distinct $\mathrm{K}^{+}$channels in cellattached patches on cells from the same preparation as was used in the present study. Three of these are apparently delayed $\mathrm{K}^{+}$ channels with a conductance of $11 \mathrm{pS}$. It is not clear if any of these correspond to either the $K_{D}$ or the $K_{1}$ channels.

\section{A channels}

The $\mathrm{A}_{2}$ channels characterized in this study are distinct from the $A_{1}$ channels, which are responsible for A current in Drosophila muscle (Solc et al., 1987). The inactivation rate of the $\mathrm{A}_{2}$ channels is insensitive to voltage and slower than the voltagedependent $A_{1}$ inactivation rate. There are also differences in the voltage dependence of activation and inactivation, which is 20 $40 \mathrm{mV}$ more positive for the $A_{1}$ channels than for the $A_{2}$ channels. Furthermore, mutations at the Shaker locus, which alter or eliminate the $A_{1}$ channels in muscle (Salkoff and Wyman, $1981 \mathrm{~b} ; \mathrm{Wu}$ and Haugland, 1985; Timpe and Jan, 1987), have no effect on the $A_{2}$ channels (Solc et al., 1987). However, the same Shaker mutations cause hyperexcitability of larval presynaptic terminals (Jan et al., 1977; Ganetzky and Wu, 1983) and abnormally long action potentials in the adult giant fiber
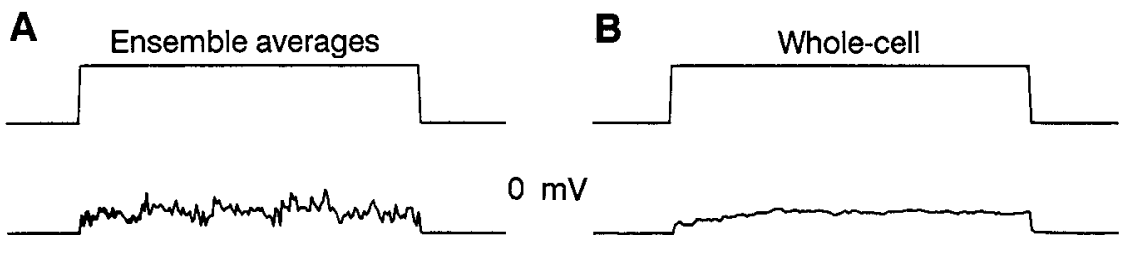
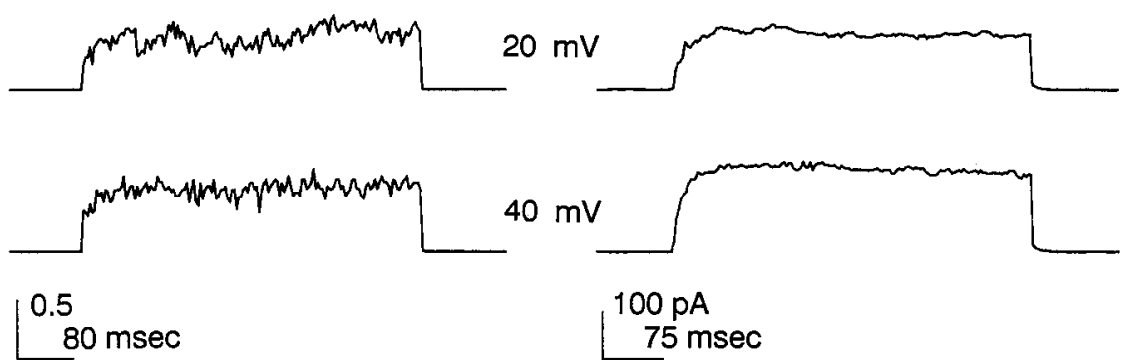

Figure 16. Ensemble averages of $\mathbf{K}_{1}$ channel currents (same channel as shown in Fig. 14;A) compared with whole-cell currents from the cell shown in Figure $1 C(B)$ at the same command voltages. Approximately 32 singlechannel traces were used to generate each ensemble average. The averages are expressed in terms of the probability of the channel being open. The prepulse voltage for the whole-cell records was $-60 \mathrm{mV}$. 
(Tanouye et al., 1981), suggesting that $A_{1}$-like channels may be present in some axons and terminals of Drosophila neurons. A possible explanation is that $A_{2}$ channels are confined to the soma of nerve cells, while $A_{1}$ channels are located in axons and terminals. It is interesting that in cases where A current has been analyzed in axons and dendrites (Connor, 1975, 1978; Mirolli, 1981; Quinta-Ferreira et al., 1982), the inactivation time course is similar to that of the $A_{1}$ channels, whereas the inactivation rate in molluscan and leech somata (Connor and Stevens, 1971; Byrne, 1980; Johansen and Kleinhaus, 1986) is more similar to that of the $A_{2}$ channels.

The $A_{2}$ channel most likely does not correspond to the fast transient $\mathrm{Ca}^{2+}$-dependent $\mathrm{K}^{+}$channel in muscle (Salkoff, 1983): $A_{2}$ channels gate normally in the absence of high internal calcium, $\mathrm{A}_{2}$ currents are not blocked by the addition of $1 \mathrm{mM} \mathrm{Cd}^{2+}$ or the removal of $\mathrm{Ca}^{2+}$ from the bath, and normal $\mathrm{A}_{2}$ currents can be recorded from flies homozygous for the slopoke mutation (generously provided by Dr. Barry Ganetzky, University of Wisconsin), which eliminates the fast transient $\mathrm{Ca}^{2+}$-dependent current in larval and pupal muscle (Elkins et al., 1986; Solc and Aldrich, unpublished observations).

Single A channels have recently been reported in several systems other than Drosophila. They are similar to the $A_{2}$ channels in that the open probability rapidly peaks and decays with time in response to depolarizing voltage steps and that they are mostly inactivated by sufficiently long prepulses to $-50 \mathrm{mV}$. They differ, however, in several important ways. The conductance and mean open times of $\mathrm{A}$ channels from rat nodose ganglion (22 pS, 15-35 msec; Cooper and Shrier, 1985) and guinea pig dorsal root ganglion ( $20 \mathrm{pS}, \sim 15 \mathrm{msec}$; Kasai et al., 1986) are both larger than those of the $\mathrm{A}_{2}$ channcls (6-8 pS, 2-5 msec). The rat nodose channels inactivate faster $(\tau=30 \mathrm{msec})$ than the $\mathrm{A}_{2}$ channels, while those from the guinea pig have slower time constants $\left(\tau_{\mathrm{f}}=100 \mathrm{msec}, \tau_{\mathrm{s}}=4000 \mathrm{msec}\right)$. The inactivation rate of the $A_{2}$ channels is perhaps most similar to that shown for ensemble averages of Helix channels $(g=14 \mathrm{pS}$; Taylor, 1987 ) and the $K_{w}$ channels from PC12 cells ( $g=14$ to $18 \mathrm{pS}$; Hoshi and Aldrich, 1988). It should be noted that the open time comparison between different channels may be misleading, as bursts of $A_{2}$ channel openings ( $10-30 \mathrm{msec}$ in duration) could be interpreted as single openings at low filter frequencies.

A fraction of the whole-cell A current is blocked by $5 \mathrm{~mm}$ 4-AP (Fig. 2A), an effect characteristic of A currents in other preparations (Thompson, 1977; see review by Rogawski, 1985). Single $\mathrm{A}_{2}$ channels in outside-out patches, however, are not measurably affected by similar concentrations of this drug. There are several interpretations for these apparently contradictory results. One possibility is that the 4-AP-sensitive current is carried by channels other than the $A_{2}$ channels. This is unlikely, since $A_{2}$ channels were the only fast transient channels that we observed in the 70 patches used in this study. Because the $\mathrm{A}$ current was present in most of the cells with active currents, and a fraction of this current was blocked in every case we applied $5 \mathrm{~mm}$ 4-AP $(n=5)$, fast transient channels in the soma distinct from the $A_{2}$ channels should have been detected if they existed. Another possibility is that the $A_{2}$ channels can only be blocked by 4-AP acting from the intracellular side of the membrane. In the whole-cell configuration, the lipophilic drug could cross the cell membrane and, due to restricted diffusion in the cell, build up to a high enough internal concentration to block the channels. In outside-out patches, however, the drug could diffuse across the membrane into a large reservoir (the patch pipette), and the concentration would not reach the levels required for block. This idea is supported by the observation that single A channels from guinea pig (Kasai et al., 1986) were not affected by externally applied $5 \mathrm{~mm} 4$-AP, but the drug reduced both the single-channel conductance and the probability of being open when applied from the inside. A conclusive test of this hypothesis is to apply 4-AP to inside-out patches with $A_{2}$ channels. We have found this difficult because stable inside-out patches were obtained only infrequently.

Variability in the inactivation rates of A currents has been observed in other preparations and may be due to a modulation of the channels. Serrano (1982) has shown that A currents in different identified cells in Andisoris have a similar voltage dependence of activation and prepulse inactivation but differ markedly in inactivation kinetics. Strong (1984) demonstrated that forskolin, presumably acting through a stimulation of the adenylate cyclase system, speeds the inactivation of $\mathrm{A}$ currents in Aplysia bag cells.

\section{$K_{D}$ channels}

The $K_{D}$ channels have a voltage dependence of activation and inactivation consistent with what has been called a delayed rectifier current (see reviews by Thompson and Aldrich, 1980, and Adams et al., 1980). They are reversibly blocked by $10 \mathrm{~mm}$ external $\mathrm{TEA}^{+}$(Fig. 14) and are insensitive to $5 \mathrm{~mm}$ external 4-AP, consistent with the interpretation that they underlie the $\mathrm{TEA}^{+}$-sensitive, 4-AP-insensitive, slowly inactivating component of whole-cell current (Fig. 2). Both the slow inactivation and $\mathrm{TEA}^{+}$sensitivity of the $\mathrm{K}_{\mathrm{D}}$ channel are similar to that observed for delayed currents in a variety of invertebrate somata prcparations (Aldrich et al., 1979; Byrne, 1980; Johansen and Kleinhaus, 1986). A slowly inactivating $\mathrm{K}^{+}$current, distinct from the A current, can also be resolved at early times in Shaker null pupal muscle (Timpe and Jan, 1987), and single channels with properties similar to the $K_{D}$ channels have been observed in Drosophila myotubes (W. N. Zagotta, M. S. Brainard and R. W. Aldrich, unpublished observations).

Single delayed $\mathrm{K}$ channels in several other preparations have been reported (Conti and Neher, 1980; Coronado et al., 1984; Ebihara and Speers, 1984; Cahalan et al., 1985; Marty and Neher, 1985; Quandt, 1988). A delayed rectifier channel isolated from frog skeletal muscle has similar gating and inactivation properties and a comparable single-channel conductance (15 pS) that increases in high (120 mM) external potassium and is blocked to $40 \%$ of control values by $10 \mathrm{~mm}$ external TEA ${ }^{+}$(Standen et al., 1985). A K ${ }^{+}$channel in mouse macrophages $(g=16 \mathrm{pS})$ inactivates with an equivalent time course $(\tau-500 \mathrm{msec})$ but is sensitive to $5 \mathrm{mM} 4-\mathrm{AP}$, as well as $\mathrm{TEA}^{+}$, at the whole-cell level (Ypey and Clapham, 1984). The 11-14 pS K $\mathrm{z}_{\mathrm{z}}$ channel in PC1 2 cells has similar mean open durations and inactivation time course but is also sensitive to $4-\mathrm{AP}$, as well as $\mathrm{TEA}^{+}(\mathrm{Hoshi}$ and Aldrich, 1988).

The variability in the voltage-dependence of prepulse inactivation of different $K_{D}$ channels may be due to a difference in the microenvironment, modulatory state, or molecular structure of the channels. We cannot distinguish among these possibilities.

\section{$K$, channels}

The voltage-dependence and gating of the $K_{1}$ channels suggests that these channels contribute to the sustained component of current in these cells. The channels have complex gating behavior. Open and closed duration histograms indicate that a 
minimal model to account for the gating of these channels would need to include at least 2 open, 3 closed states, and a long-lived inactivated state. The complexity of gating and the variability in the relationship between open probability and voltage suggest that factors in addition to the transmembrane voltage may regulate the gating process of these channels. Similar channels have been observed in other cell types. The "slow" $\mathrm{K}^{+}$channels in neurons from the mollusk Lymnae stagnalis have a conductance of $30 \mathrm{pS}$ and exhibit similar gating properties and fluctuations in the single-channel current (Kazachenko and Geletyuk, 1984).

\section{Conclusions}

We have identified 3 classes of voltage-dependent $\mathrm{K}^{+}$channels that are sufficient to account for the $\mathrm{K}^{+}$currents observed in the whole-cell configuration. The identification of mutations that affect these channels, and the isolation of their genes will provide insights into the role that these channels play in an intact organism, and into the molecular relationships among the different types of voltage-dependent $\mathrm{K}^{+}$channels. The variability in some of the single-channel properties suggests that the channels may be modulated, and an analysis of channels from flies mutant in proteins involved in modulation may provide insights into the regulation of channels by second messengers. Detailed information about the voltage-dependent gating of the individual channel types in wild-type flies can be used to construct kinetic models of channel gating, which, when compared with models of channels altered by mutations, can lead to an increased understanding of the molccular mechanisms underlying channel function.

\section{References}

Adams, P. R., and M. Galvan (1986) Voltage-dependent currents of vertebrate neurons and their role in membrane excitability. Adv. Neurol. 44: 137-170.

Adams, D. J., S. J. Smith, and S. H. Thompson. (1980) Ionic currents in molluscan soma. Annu. Rev. Neurosci. 3: 141-167.

Aldrich, R. W., P. A. Getting, and S. H. Thompson. (1979) Inactivation of delayed outward current in molluscan neurone somata. $J$. Physiol. (Lond.) 291: 507-530.

Byerly, L., and W. J. Moody (1986) Membrane currents of internally perfused neurones of the snail, Lymnae stagnalis, at low intracellular pH. J. Physiol. (Lond.) 376: 477-491.

Byrne, J. II. (1980) Analysis of ionic conductance mechanisms in motor cells mediating inking behavior in Aplysia californica. J. Neurophysiol. 43: 630-650.

Cahalan, M. D., K. G. Chandy, T. E. DeCoursey, and S. Gupta (1985) A voltage-gated potassium channel in human T lymphocytes. J. Physiol. (Lond.) 358: 197-237.

Colquhoun, D., and F. J. Sigworth (1983) Fitting and statistical analysis of single channel records. In Single Channel Recording, B. Sakmann and E. Neher, eds., pp. 191-264, Plenum, New York.

Connor, J. A. (1975) Neural repetitive firing: A comparative study of membrane properties of crustacean walking leg axons. J. Neurophysiol. 38: 922-932.

Connor, J. A. (1978) Slow repetitive activity from fast conductance changes in neurons. Fed. Proc. 37: 2139-2145.

Connor, J. A., and C. F. Stevens (1971) Voltage clamp studies of a transient outward membrane current in gastropod neural somata. J. Physiol. (Lond.) 213: 21-30.

Conti, F., and E. Neher (1980) Single channel recordings of $\mathrm{K}^{+}$currents in squid axons. Nature 285: 140-143.

Cooper, E., and A. Shrier (1985) Single-channel analysis of fast transient potassium currents from rat nodose neurones. J. Physiol. (Lond.) 369: 199-208.

Coronado, R., and C. Miller (1979) Voltage-dependent caesium blockade of a cation channel from fragmented sarcoplasmic reticulum. Nature 280: 807-810.
Coronado R., R. Latorre, and H. G. Mautner (1984) Single potassium channels with delayed rectifier behavior from lobster axon membranes. Biophys. J. 45: 289-299.

Ebihara, L., and W. C. Speers (1984) Ionic channels in a line of embryonal carcinoma cells induced to undergo neuronal differentiation. Biophys. J. 46: 827-830.

Elkins, T., B. Ganetzky, and C.-F. Wu (1986) A Drosophila mutation that eliminates a calcium-dependent potassium current. Proc. Natl. Acad. Sci. USA 83: 8415-8419.

Ganetzky, B., and C.-F. Wu (1983) Neurogenetic analysis of potassium currents in Drosophila: Synergistic effects on neuromuscular transmission in double mutants. I. Neurogenet. 1: 17-28.

Ganetzky, B., and C.-F. Wu (1986) Neurogenetics of membrane excitability in Drosophila. Annu. Rev. Genet. 20: 13-44.

Hagiwara, S., K. Kusano, and N. Saito (1961) Membrane changes of Onchidium nerve cell in potassium-rich media. J. Physiol. (Lond.) 155: 470-489.

Hamill, O. P., A. Marty, E. Neher, B. Sakmann, and F. J. Sigworth (1981) Improved patch clamp techniques for high-resolution current recording from cells and cell-free membrane patches. Pfluegers Arch. 391: 85-100.

Hoshi, T., and R. W. Aldrich (1988) Voltage-dependent $\mathrm{K}^{+}$currents and underlying single $\mathrm{K}^{+}$channels in pheochromocytoma cells. $\mathrm{J}$. Gen. Physiol. 91: 73-106.

Jan, L. Y., and Y. N. Jan (1982) Antibodies to horseradish peroxidase as specific neuronal markers in Drosophila and in grasshopper embryos. Proc. Natl. Acad. Sci. USA 79: 2700-2704.

Jan, Y. N., L. Y. Jan, and M. J. Dennis (1977) Two mutations of synaptic transmission in Drosophila. Proc. R. Soc. London [Biol.] 198: 87-108.

Johansen, J., and A. L. Kleinhaus (1986) Transient and delayed potassium currents in the Retzius cell of the leech, Macrobdella decora. J. Neurophys. 56: 812-822.

Kasai, H., M. Kameyama, K. Yamaguchi, and J. Fukuda (1986) Single transient $\mathrm{K}$ channels in mammalian sensory neurons. Biophys. J. 49: 1243-1247.

Kazachenko, V. N., and V. I. Geletyuk (1984) The potential-dependent $\mathrm{K}^{+}$channel in molluscan neurones is organized in a cluster of elementary channels. Biochem. Biophys. Acta 773: 132-142.

Komatsu, A., Y.-A. Sun, and C. F. Wu (1986) Different types of potassium channels in CNS neurons of Drosophila. Soc. Neurosci. Abstr. 12: 1341 .

Latorre, R., R. Coronado, and C. Vergara (1984) $\mathrm{K}^{+}$channels gated by voltage and ions. Annu. Rev. Physiol. 46: 485-495.

Marty, A., and E. Neher (1985) Potassium channels in cultured bovine adrenal chromaffin cells. J. Physiol. (Lond.) 367: 117-141.

Mirolli, M. (1981) Fast inward and outward current channels in a nonspiking neurone. Nature 292: 251-253.

Neher, E. (1971) Two fast transient current components during voltage clamp on snail neurons. J. Gen. Physiol. 58: 36-53.

Papazian, D. M., T. L. Schwarz, B. L. Tempel, L. C. Timpe, and L. Y. Jan (1988) Ion channels in Drosophila. Annu. Rev. Physiol. 50: 379-394.

Quandt, F. N. (1988) Three kinetically distinct potassium channels in mouse neuroblastoma cells. J. Physiol. (Lond.) 395: 401-418.

Quinta-Ferreira, M. E., E. Rojas, and N. Arispe (1982) Potassium currents in the giant axon of the crab Carcinus maenas. J. Membr. Biol. 66: 171-181.

Rogawski, M. A. (1985) The A-current: How ubiquitous a feature of excitable cells is it? Trends Neurosci. 8: 214-219.

Rudy, B. (1988) Diversity and ubiquity of K channels. Neuroscience (in press).

Salkoff, L. B. (1983) Drosophila mutants reveal two components of fast outward current. Nature 302: 249-251.

Salkoff, L. B., and M. A. Tanouyc (1986) Genetics of ion channels. Physiol. Rev. 66: 301-329.

Salkoff, L. B., and R. Wyman (1981a) Outward currents in developing Drosophila flight muscle. Science 212: 461-463.

Salkoff, L. B., and R. Wyman (1981b) Genetic modification of potassium channels in Drosophila Shaker mutants. Nature 293: 228230.

Sang, J. H. (1981) Drosophila cells and cell lines. Adv. Cell Culture 1: $125-183$.

Serrano, E. E. (1982) Variability in molluscan neuron soma currents Ph.D. thesis, Stanford University. 
Solc, C. K., and R. W. Aldrich (1985) Patch clamp analysis of inactivating outward currents in dissociated neurons of wild-type and Shakers Drosophila. Soc. Neurosci. Abstr. 11: 954.

Solc, C. K., and R. W. Aldrich (1986) Macroscopic and single-channel potassium currents in dissociated Drosophila CNS neurons. Soc. Neurosci. Abstr. 12: 44.

Solc, C. K., W. N. Zagotta, and R. W. Aldrich (1987) Single-channel and genetic analyses reveal two distinct A-type potassium channels in Drosophila. Science 236: 1094-1098.

Standen, N. B., P. R. Stanfield, and T. A. Ward (1985) Properties of single potassium channels in vesicles formed from the sarcolemma of frog skeletal muscle. J. Physiol. (Lond.) 364: 339-358.

Strausfield, N. J. (1976) An Atlas of Insect Brain, pp. 13-18, 50-52 Springer-Verlag, New York.

Strong, J. (1984) Modulation of potassium current kinetics in bag cell neurons of Aplysia by an activator of adenylate cyclase. J. Neurosci. 4: $2772-2783$

Sun, Y.-A., and C.-F. Wu (1984) Voltage-dependent single-channel currents in dissociated CNS neurons of Drosophila. Soc. Neurosci. Abstr. 10: 1091 .

Tanouye, M. A., A. Ferrus, and S. C. Fujita (1981) Abnormal action potentials associated with the Shaker complex locus of Drosophila. Proc. Natl. Acad. Sci. USA 78: 6548-6552.

Tanouye, M. A., C. A. Kamb, L. E. Iverson, and L. B. Salkoff (1986) Genetics and molecular biology of ionic channels in Drosophila. Annu. Rev. Neurosci. 9: 255-276.

Taylor, P. S. (1987) Selectivity and patch measurements of A-current channels in Helix aspersa neurones. J. Physiol. (Lond.) 388: 437447.

Thompson, S. H. (1977) Three pharmacologically distinct potassium channels in molluscan neurones. J. Physiol. (Lond.) 265: 465-488.

Thompson, S. H., and R. W. Aldrich (1980) Membrane potassium channels. In The Cell Surface and Neuronal Function, C. W. Cotman, G. Poste, and G. L. Nicolson, eds., pp. 49-85, Elsevier/North Holland Biomedical, Amsterdam.

Timpe, L. C., and L. Y. Jan (1987) Gene dosage and complementation analysis of the Shaker locus in Drosophila. J. Neurosci. 7: 1307-1317.

Wei, A., and L. B. Salkoff (1986) Occult Drosophila calcium channels and twinning of calcium and voltage-activated potassium channels. Science 23: 780-782.

Wu, C.-F., and F. N. Haugland (1985) Voltage clamp analysis of membrane currents in larval muscle fibers of Drosophila: Alteration of potassium currents in Shaker mutants. J. Neurosci. 10: 2626.

Wu, C.-F., B. Ganetzky, F. N. Haugland, and A. X. Liu (1983a) Potassium currents in Drosophila: Different components affected by mutations of two genes. Science 220: 1076-1078.

Wu, C.-F., N. Suzuki, and M.-M. Poo (1983b) Dissociated neurons from normal and mutant Drosophila larval central nervous system in cell culture. J. Neurosci. 3: 1888-1899.

Yamamoto, D., and N. Suzuki (1987) Blockage of chloride channels by HEPES butfer. Proc. R. Soc. London [Biol.] 230: 93-100.

Ypey, D. L., and D. E. Clapham (1984) Development of a delayed outward-rectifying $\mathrm{K}^{+}$conductance in cultured mouse peritoneal macrophages. Proc. Natl. Acad. Sci. USA 81: 3083-3087. 